\title{
العنف الاسري والمرأة العاملة دراسة ميدانية في مدينة الديوانية
}

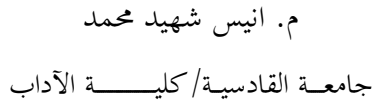

$$
\begin{aligned}
& \text { قسم علم الاجتماع }
\end{aligned}
$$

\section{Abstract:}

The present study deals with a very important issue concerning the family, which is the first structure in the society, namely the violence directed at women by the members of their family towards it, namely the working woman who introduced herself in a difficult life in an unjust and inequitable society that sacrificed and sacrificed for the happiness of her family, And despite the seriousness of this phenomenon on the community and the family in particular, but we note the increase in recent times in all communities, especially the Iraqi society due to the conditions experienced by the security breaches and violations of the law and non-respect, and in order to achieve the basic objectives of the current study has been selected The sample is composed of (120) respondents to measure family violence directed against working women. This study is an analytical descriptive study. In this study, the social survey method was used. The questionnaire was used to obtain data. (20-30 years) are the most age group exposed to domestic violence. Most of the educational groups are exposed to university degrees. The female respondents are found to be more vulnerable to domestic violence. Most of the educational groups are subjected to violence by university degree holders, And Ghaleb The economic factor plays an important role in the perpetration of violence against women within the family and the economic abuse of women. Economic abuse has been shown to play an important role in the perpetration of violence against women within the family, The multiplicity of forms of violence faced by women is physical and moral violence, physical violence is the beating is one of the most important forms of violence towards the wife, followed by moral violence represented in irony, betrayal and abandonment.

تتناول الدراسة الحالية موضوع في غاية الاهمية يخص الاسرة وهي البنيه الاولى في المجتمع الإوهو العنف الموجه المى المرأة الذي يقوم به افراد اسرتا تجاهها

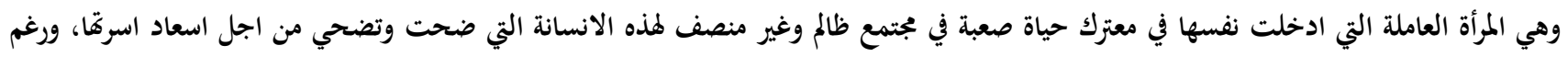

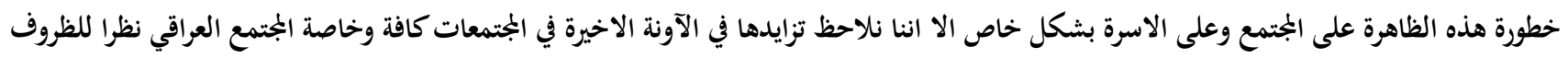

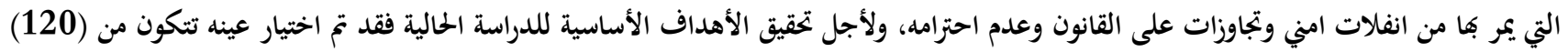

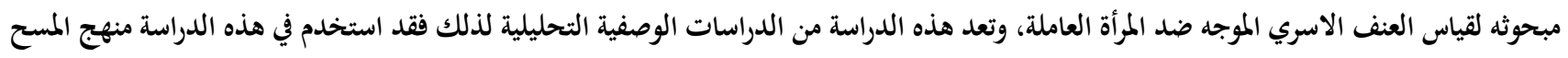

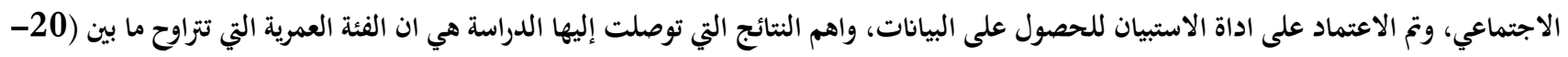

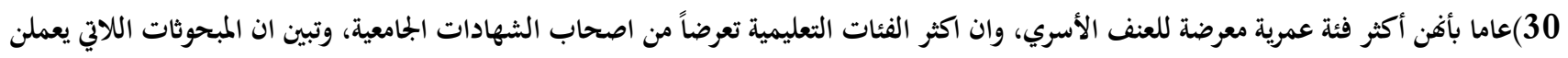

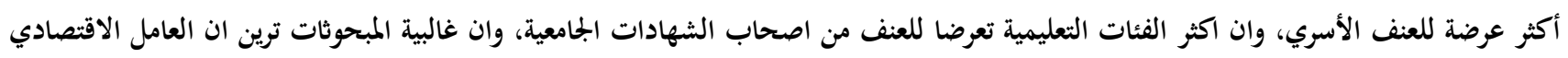

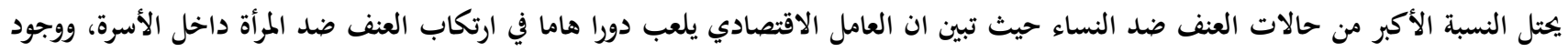

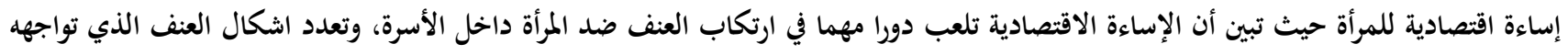

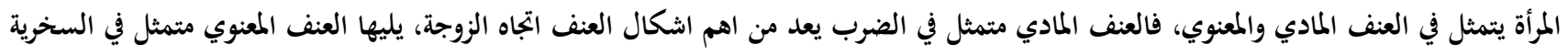
والحيانة والهجر. 
1- مشـكلة البحث: تدور إثــكالية البحث حول قضــية عمل المرأة في

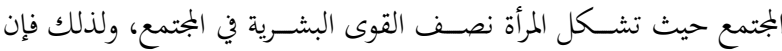

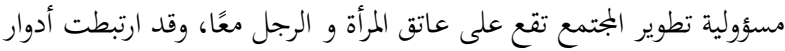
المرأة تاريخيًا وفي مختلف المجتمعات الإنســانية بنظرة هذه المجتمعات إلى المرأة ومكانتها، وعلى ضـــوء هذه المكانة يتم تحديد أدوارها ومســـــولياتما بتحاه

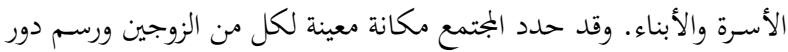

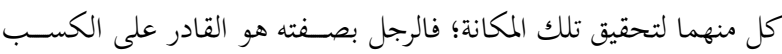

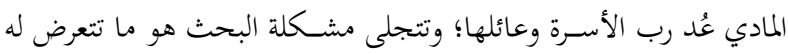

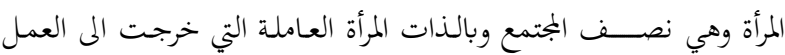
لمسـاعدة عائلتها ولكنها بالمقابل لم تحصل إلا على التعنيف من هذه العائلة

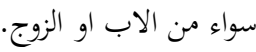

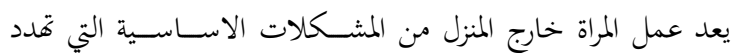
استقرار الاسرة لان في ذلك اقصاء لها عن ادوارها الاساسية وهي الامومة لراه الزوجية فهي مسؤولة عن بناء الاسرة وتنشئة الابناء، وعملها خارج بيتها

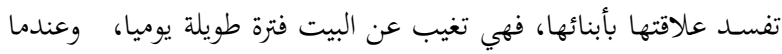
تعود الي البيت تكون جههدة متعبة وبحاجة الى الراحة ، وبذا يفقد الابناء

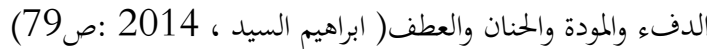

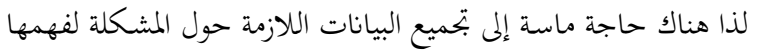

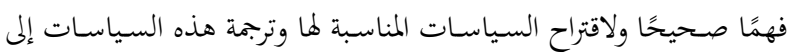

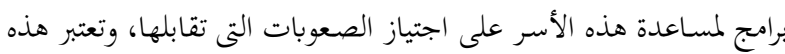
الدراسة خطوة فن سبيل تحقيق هذا الهدف.

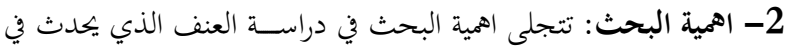

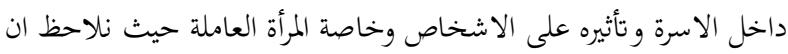
خروج المرأة للعمل ومشاركة الرجل زادها اعباء اضافة الى الاعباء التي كانت

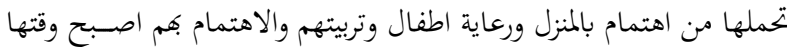

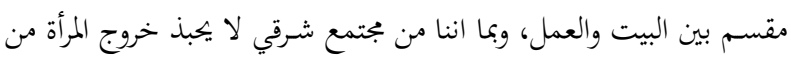

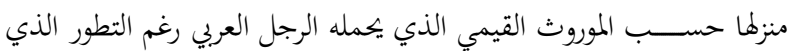

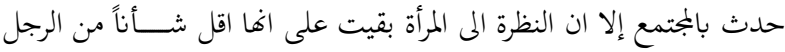
وعليها ان ترعاه وتســـهر على راحته مهما وصــلت من العلم او المركز

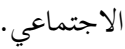
ويشهد واقعنا الحالي تزايدًا في بروز العنف في عدد الأسر التي تعمل فيها النساء، وبالرغم من ذلك لا يوجد حتى الآن جهد موجه أصلاً لدراسة هذه

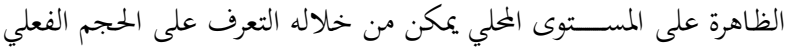

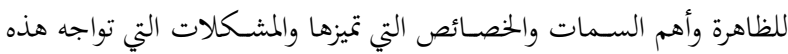
الفئة، لذا جاء الاهتمام همذا الموضـــوع نســبيًا؛حيث تم تناوله في إطار

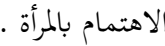
ولقد جاءت الأهية النظرية للدراسة الراهنة في كونا محاولة للإسهام في

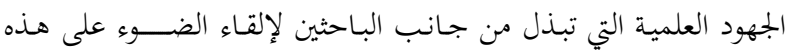

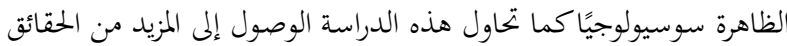

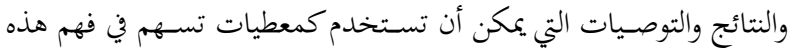

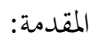
تعد الأســرة الوحدة الأولية التي قامت عليها أغلب المجتمعات، ولقد

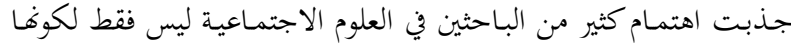

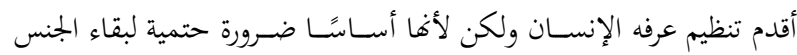

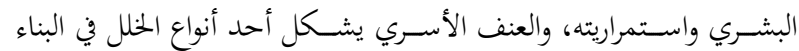

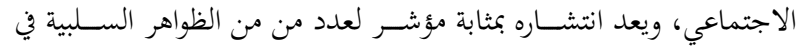

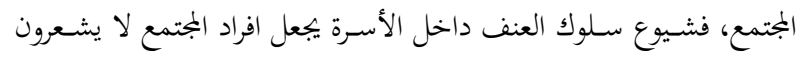

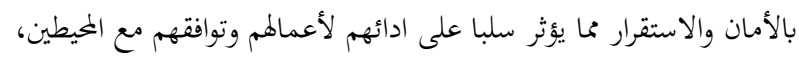
ولذا تعد ظاهر العنف الاسـري، والعنف الموجه ضـــ المرأة بالتحديد ظاهرة ذات ابعاد تاريخية وحضارية وبجتمعية، فهي ليست قاصرة على مكان دون آلئن

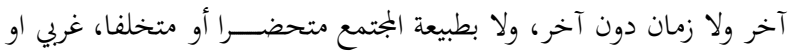

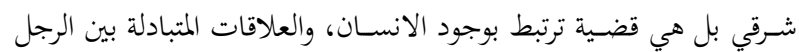

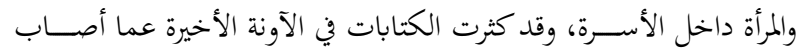

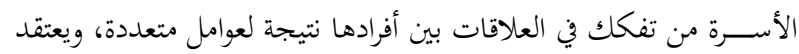
البعض أن هذا التفكك الذي نقرأ ونسـمع عنه قد أصـاب الأسـرة، والمرأة بشـكل خاص حيث نلاحظ ان العنف الاسـري ضــ المرأة، وخاصـة المرأة

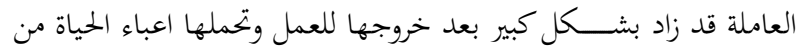
مسؤولية البيت ورعاية اطفال واعالتهم اضـافة المى اعباء العمل ومسؤولياتها

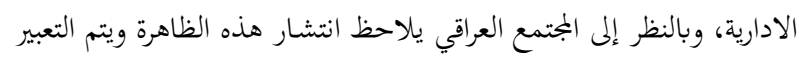

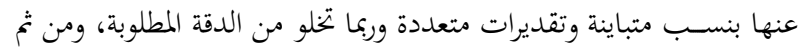

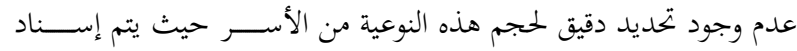

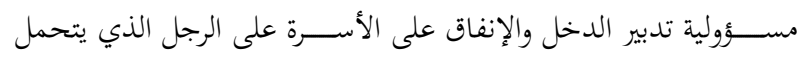

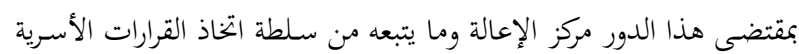

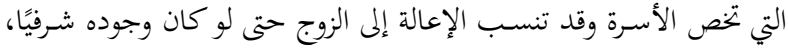

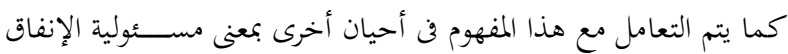
على الأسرة وفي هذا تقليص لمعنى المسؤولية وإعالة الأسرة.

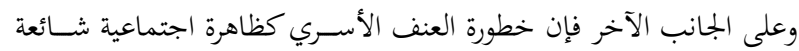
تكمن في ان نتائجها ليست مباشرة فقط التي نلمسها على الأسرة، بل لها

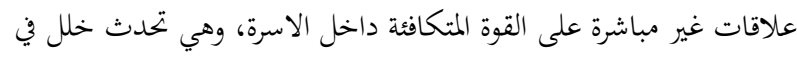

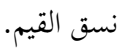

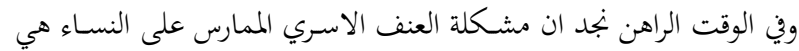

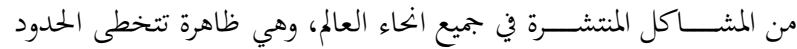

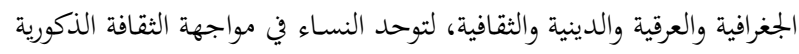

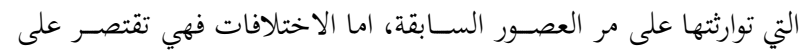

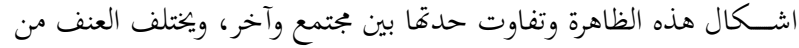

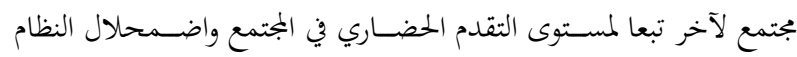

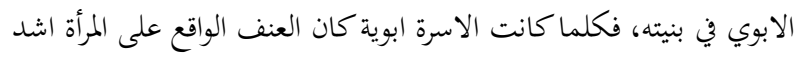

واكبر. أولاً: الإطار التصوري للبحث 
وبالتعرض لمفهوم العنف من وجهة النظر القانونية يفرق بعض القانونيين

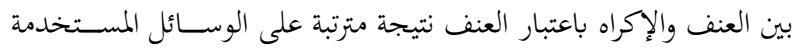
لقهر الإرادة والتي قد تكون مادية متمثلة في العنف، أو معنوية متمثلة في التهديد، وعلى خلاف ذلك التمييز بين العنف والإكراه نجد باســتطلاع أقوال الفقهاء خلطهم بينهما باستعمالهما كألفاظ مترادفة (صالح ، 2003

ويعرف العنف بحســب موســوعة الجحيمة والعدالة على أنه "كل صــور

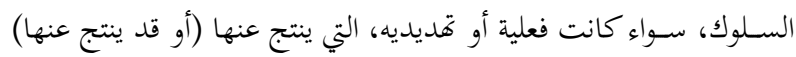
تدمير وتحطيم للممتلكات أو إلحاق الأذى أو الموت للفرد" (زايد ،2000:

وبالنظر للعنف من وجهة النظر السيكولوجية، يرى علماء النفس أنه نمط من أنماط السـلوك ينتج عن حالة إحباط ويكون مصـحوباً بعلاقات التوتر، ويحتوي على نية سـيئة لإلحاق ضــرر مادي أو معنوي بكائن حي أو بديل

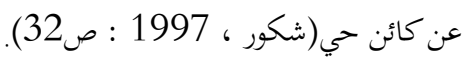

ولكن البعض الآخر عرف العنف بأنه يعني أحد الأنماط السـلوكية الفردية

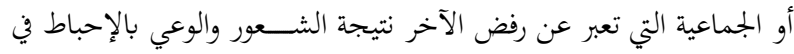
إشـباع الحاجات الإنســانية، ويدفع العنف إلى قدرات نفسـية لدى الفرد تساعدها ظروف موضوعية (اقتصادية وسياسية واجتماعية) ترتبط بخصوصية

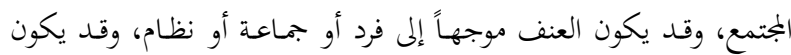

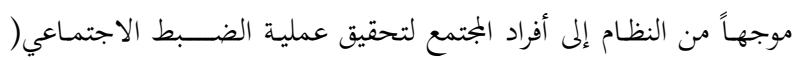

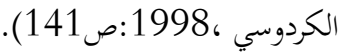
ويشــير العنف الى كل ما يربك النظام الاجتماعي والعلاقات القائمة بين

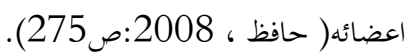
ويعرف العنف ايضا الاستخدام المتعسف للقوة، كما انه عمل موجه ضد

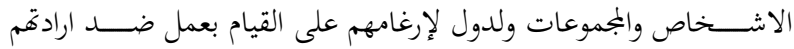

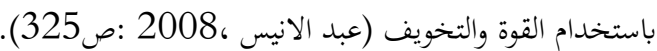

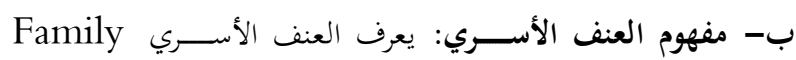
Violence أو الزوجة أو أحد الأبناء على سبيل المثال) ضد نفسه أو ضد باقي أعضاء الأســـرة، وهو ســـلوك لا اجتماعي يتعارض مع قيم المجتمع، ويهلدد كيان

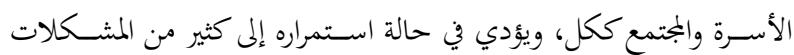

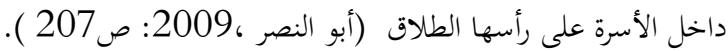

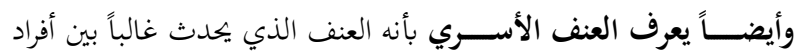

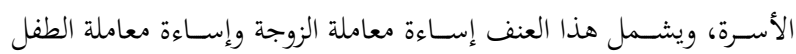
وإســاءة معاملة الكبار الســن ويف المقابل هناك ما يعرف بالعنف المجتمعي وهو عنف يقع على آخرين خارج المنزل بين أشـخاص لا توجد بينهم صـلة

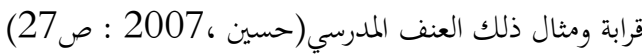

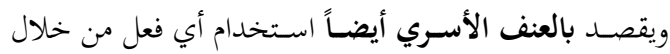
أحد أعضـاء الأسـرة ضـد عضو عائلي آخر الذي يتسـبب في ضـرر أو الم

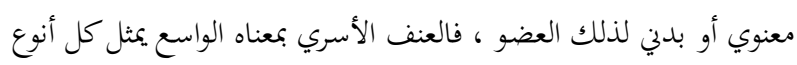

الآثار ووســـائل بتحنبها مما يحقق الاســـفـادة العامة بعد توجيهـها الوجهة الصـحيحة، كما تحاول هذه الدراسـة أيضًا إثراء الجانب النظري لفرعين في

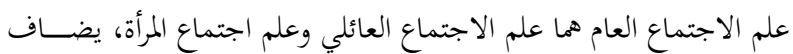

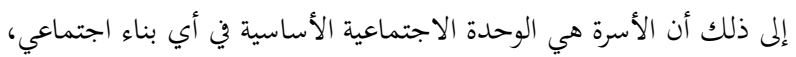

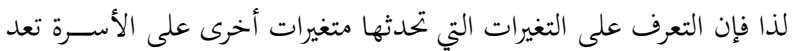
مطلبًا هامًا و ضروريًا لتوجيه هذه التغيرات لصالح الأسرة.

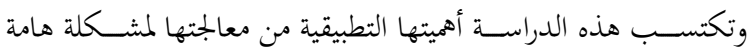

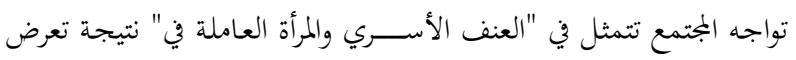

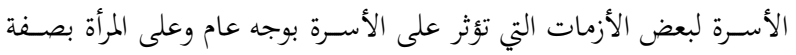

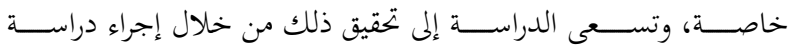

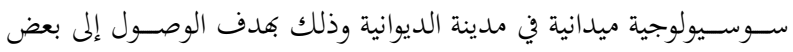
النتائج الأمبريقية التي تدور حولها بعض التساؤلات الرئيسية للدراسة.

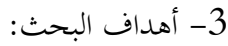
أ- التعرف على العوامل المؤدية إلى العنف ضد المرأة العاملة في ظل المتغيرات المعاصرة. ب- التعرف على مظاهر العنف السائدة ضد المرأة العاملة من قبل الأسرة. ج- التعرف على اشكال العنف الاسري ضد المرأة العاملة. 4- 1 - تساؤلات البحث:

أ- ما العوامل المؤدية إلي العنف بين الأزواج في ظل المتغيرات المعاصرة ؟ ب- ما مظاهر العنف السائدة ضد المرأة العاملة من قبل الأسرة ؟ ج- ما اشكال العنف الاسري ضد المرأة العاملة؟ ماهد العنف 5- مفاهيم البحث

أ- مفهوم العنف: فمن النساحيـة التـاريخيـة واللغويـة، يرى توماس بلات "Thomasplat " الكلمة اللاتينية Vis (أي القوة) و lalus وهي ماضسي كلمة Fero والتي تعني (يحمل) وهذه الكلمة Violence تعني (حمل القوة بحاه شـيء أو شخص) ( توماس بلات , صنمل وهده (18). أما المعنى اللغوي لكلمة "العنف" في المعجم العربي الأسـاسـي على أنه: (أ) عنف: استخدام القوة استخداماً غير مشروع أو غير مطابق للقانون. (ب) عنف - يعنف - عنفاً - عنيفاً: أخذه بشدة وقسوة أو لامه بشدة. (ج) عنف: من يأخسـ غيره بقوة وقســـوة ( المعجم العربي 1989:

كما يشـتق مفهوم العنف في اللغة الإنجليزية من "To Violate" بمعنى

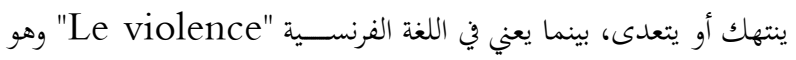
الإكراه المادي الواقع على شــص لإجباره على سـلوك أو التزام ما وبعبارة

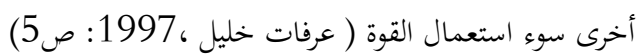

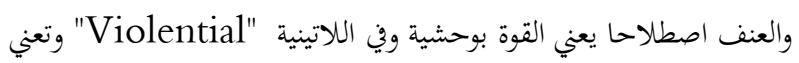

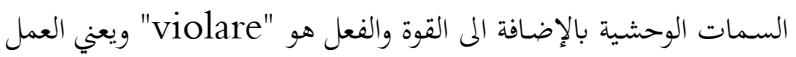

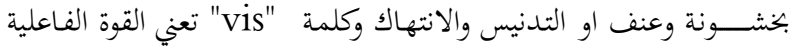

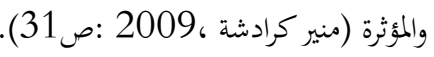


2- المستوى النفسي الاجتماعي: يفترض أن العنف والايذاء من الممكن

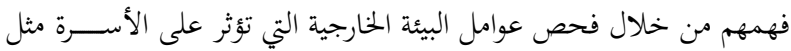

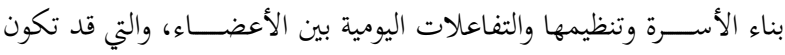
مؤشـــر لحدوث العنف، كما يركز على الاتحاهات النظرية التي تختبر بناء

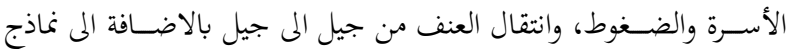

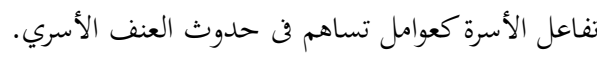

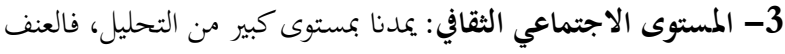

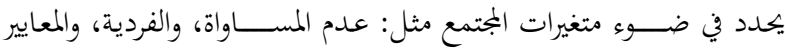
الثقافية، والاتجاهات السائدة حول العنف، والعلاقات الأسرية.

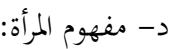
والمرأة هي انتى الانسان البالغة كما الرجل هو ذكر الانسان البالغ ، ويعرف البران

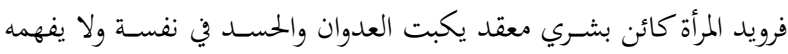

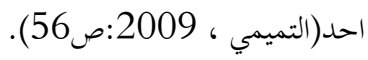

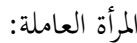

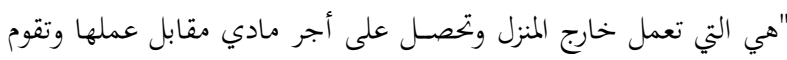
في نفس الوقت بأدوارها الأخرى كزوجة وأم إلى جانب دانعل دورها كعاملة

$$
\begin{aligned}
& \text { وموظفه(السبيعي،2010 :ص123). } \\
& \text { ثانياً: خصائص العنف الاسري } \\
& \text { 1- العنف الاسري ظاهرة عالمية: }
\end{aligned}
$$

يعد العنف الاســري ظاهرة عالمية لما يمثله من ظاهرة اجتماعية كونية، ارتبط وجودها بوجود الانسان داخل الاسرة في كافة المجتمعات البشرية على لهانى مر العصور فلا تخلو دولة من تبعات هذه الظاهرة ولكن عالمية تلك الظاهرة لا تعني بالضـرورة وجود تشـابه في نظرة المجتمعات المختلفة لها؛ إذ إنها تعتبر

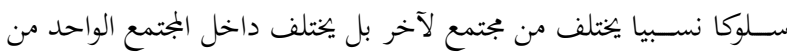

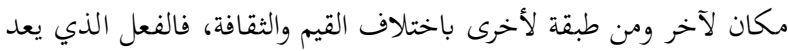

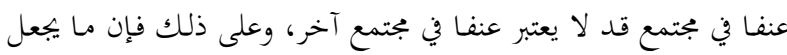

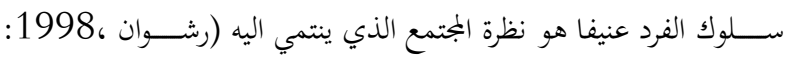

فالعنف ضـــــ المرأة ظاهرة عالمية تعاني منها المرأة في كل مكان، وأينما

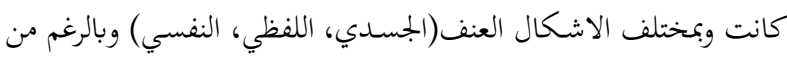

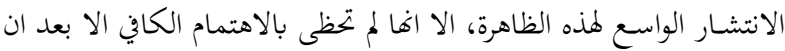

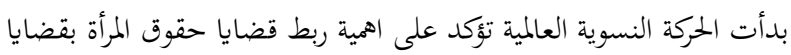

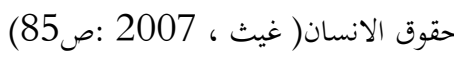

$$
\begin{aligned}
& \text { 2- تعدد مستويات العنف الأسري: }
\end{aligned}
$$

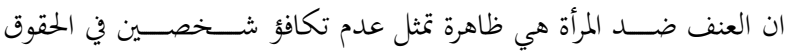
والواجبات الثقافية والاجتماعية مرتبطين بعقد زواج لتأسـيس نواة اجتماعية

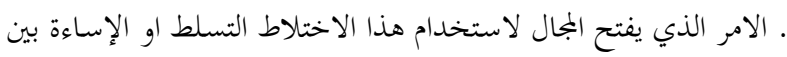

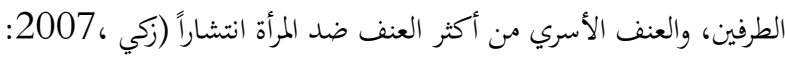

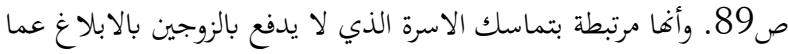

الاضطهاد كانت نفسية أو جسـدية أو جنسية التى توجه من شخص إلى آخر داخل العائلة (p340:Ambrosino , 2001: ) كما عرفه البعض بأنه " الإيذاء عن طريق الاعتداء بالقوة ولكن ليس فقط

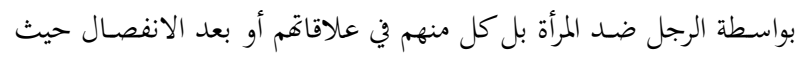

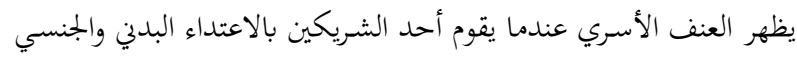

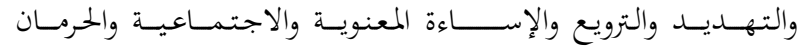

الاقتصادي(Bobic Lesely, 2002,p115).

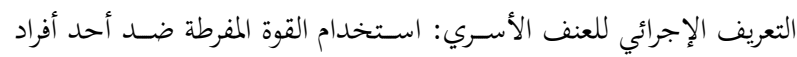

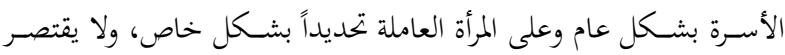
العنف الأسري على الاعتداء الجسدي فقط بل العنف بكل أشكاله الإهمال معنوية - نفسية - جنسية - اقتصادية.

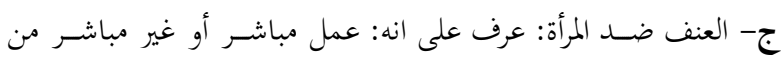

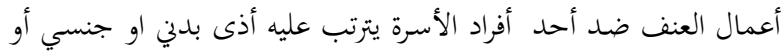

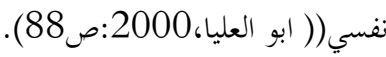

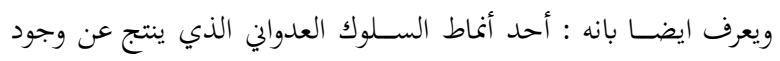

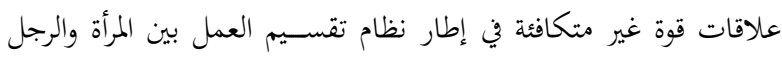

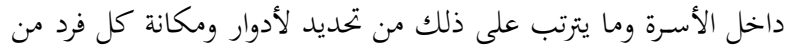

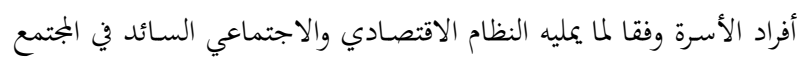

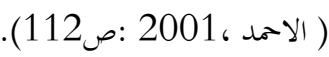

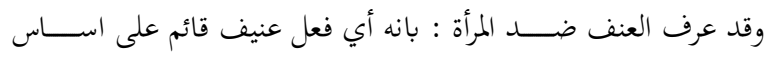
الجنس ينجم عنه او يكتمل ان ينجم عنه اذى او معاناة جنسية او جسـميه

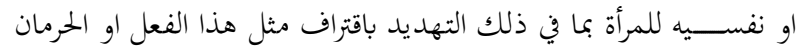

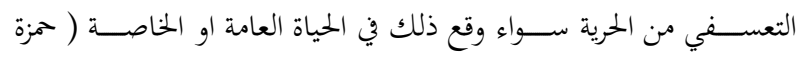

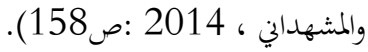

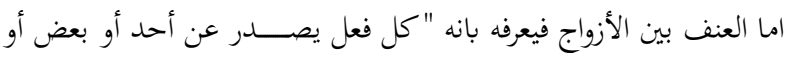

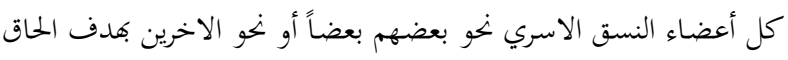

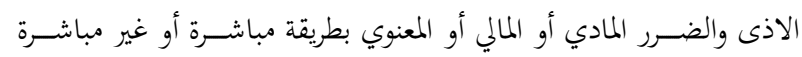

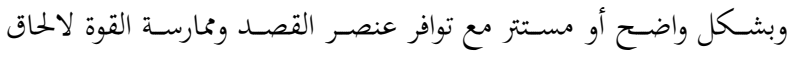

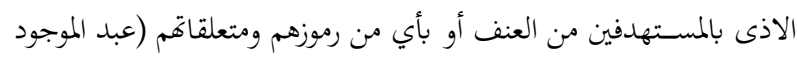

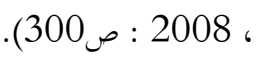
ويعرف العنف بين الأزواج بانه "كل عنف ئل يقع في اطار العائلة ومن قبل

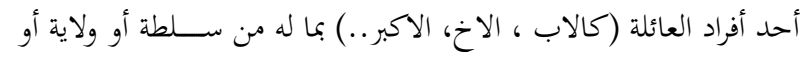
علاقة بالمعنف ( مكي ،2008 :صواد العائل (كالاب، الاخ، الاكر).

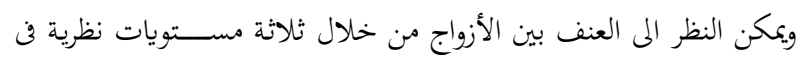

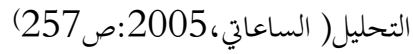

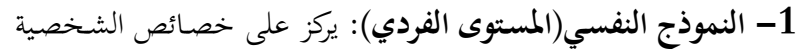

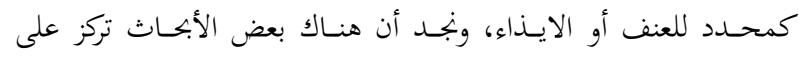

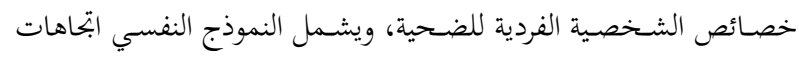

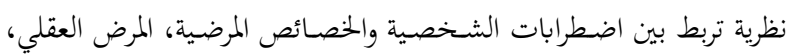

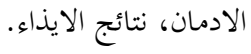


وهناك من يقسـم العنف ثلاثياً إلى عنف منظم وتلقائي ومرضسي. ويقصـد بالعنف المنظم ذلك العنف الذي يكون نتيجة تخطيط وتدبير وهو أكثر

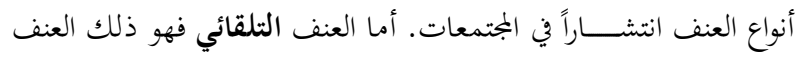

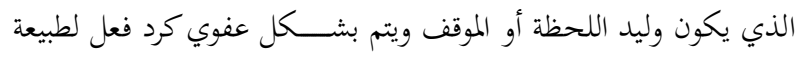

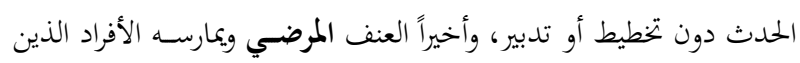
يعانون من أمراض عضوية أو نفسية أو عقلية أو عصبية يولد لديهم رغبة في ارتكاب العنف (Walker , 1999 ; pp.21-29). كذلك هناك تقســيم ثلاثي آخر للعنف العنف البدلي وهو الذي يتســمـ

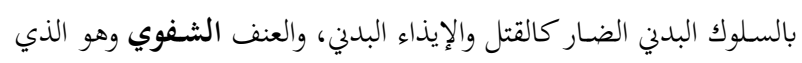

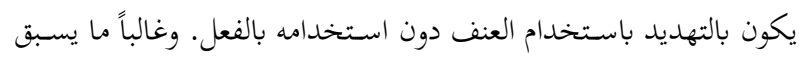

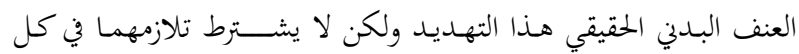
الأحوال، والعنف بالتسلط على الآخرين لإحداث نتائج اقتصادية ونفسية

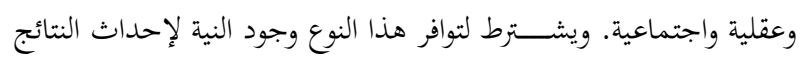

الضارة) (Williams, R. 1992,pp.620-622) 2- اشكال العنف الاسري: هناك عدة أشكال للعنف الاسرى تتمثل في (البصري ،2008:صنال 297):

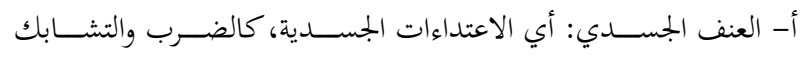

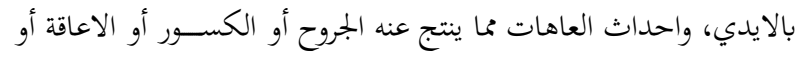

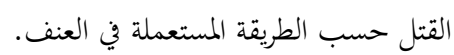
ب- العنف المعنوي والنفسي: أي الاعتداءات النفسية والمعنوية، أي اللجوء

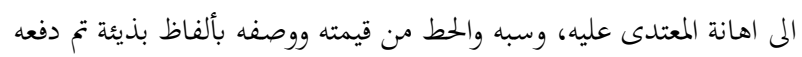
الى الانطواء وفقدان الثقة بالنفس. ج- العنف المادي: ويعرف بالعنف الاقتصادى أي حرمان أحد أفراد الاسرة من حقوقه المادية كالاكل والمصروف المالي وغير ذلك .

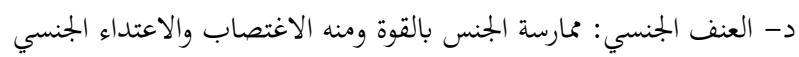
على المحرمات وغير ذلك. هـ العنف السـلطوي والاجتماعي: أي فرض العزلة على أحد أفراد الاسـرة من قبل الاب أو الام وتقييد حركة الابناء بعدم الاختلاط بالاخرين .

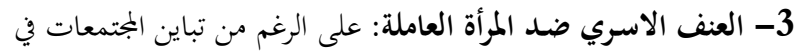

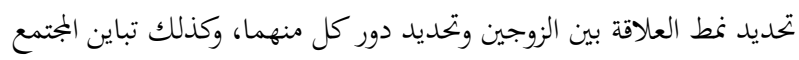

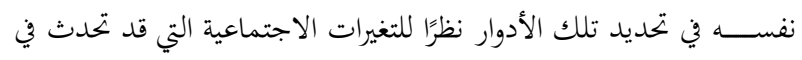

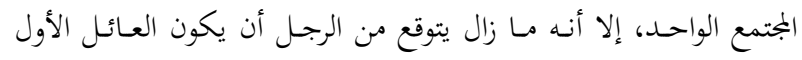
لأســته. فلعل من الظواهر التي جدت على الأسـرة هو تمركز الأسـرة حول

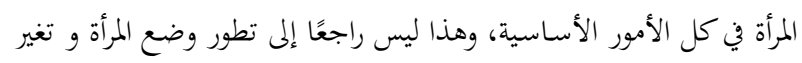

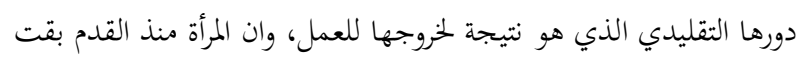

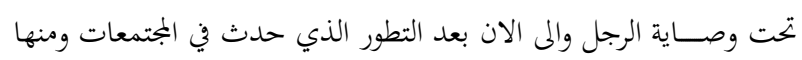

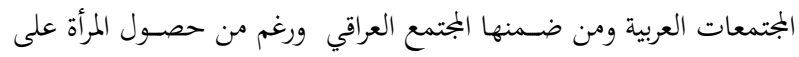

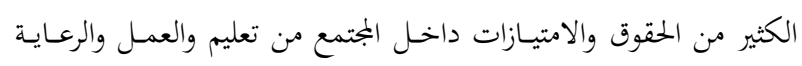

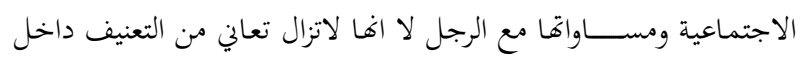
اسرها رغم من خروجها للعمل.
حدث بينهم الا للمقربين جدا من الاسرة، وأها مستترة ومتخفية في الغالب لا تمارس امام الآخرين لاهما تقع داخل المنازل.

3- العنف الاسري ظاهرة مركبة:

يعد العنف الاســري ظاهرة مركبة لما تمتاز به من تعدد ابعادها الاقتصـادية

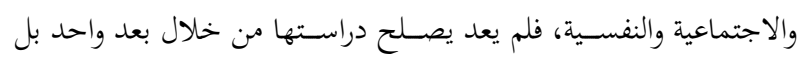

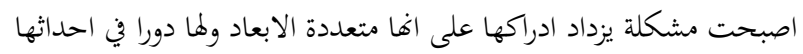
والتأثير عليها، لذا تعددت العوامل التي تقف وراء حدوث هذه الظاهرة (

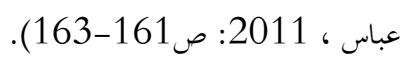
ثالثاً: طبيعة العنف الاسري ضد المرأة واشكاله 1- طبيعة العنف الاسـري: العنف الاسـري قد اصسبح منتشـرا في المجتمع المعاصـر وقد اصسبحت هناك حالات كثيرة من سـوء اسـتخدام او اسـاءة

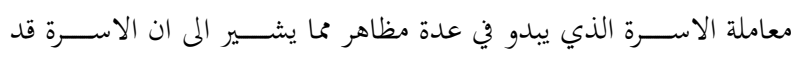

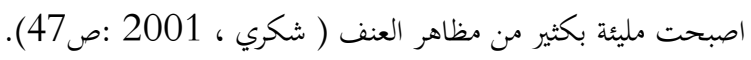

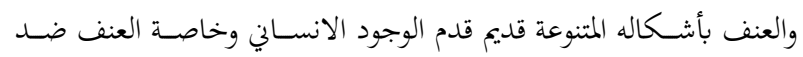

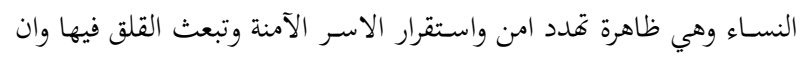
العنف هو صفة انسانية للطبيعة البشرية للأفراد ولقد عانت المرأة منذ الازل هذا التعنيف ضـدها من قبل الرجل حيث نلاحظ ذلك في كتابات ارسطو أنسو

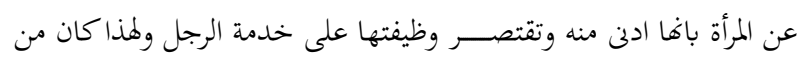

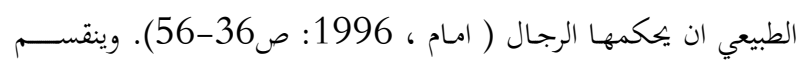

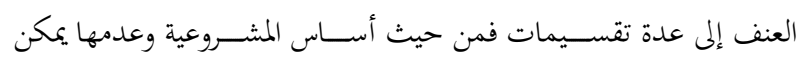

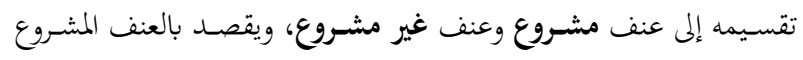

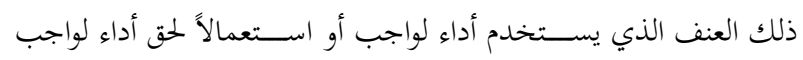

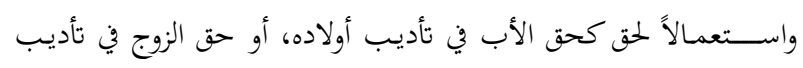
زوجته أو الحق في ممارسـة الألعاب الرياضسية العنيفة كالملاكمة أو المصـارعة.

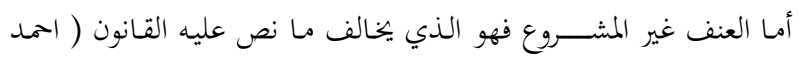

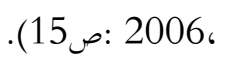
وهناك من يصنف العنف إلى عنف فطري وعنف مكتسب ويقصد بالعنف :صناف

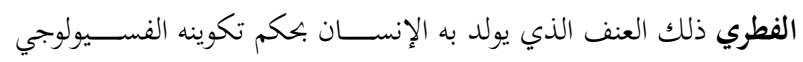

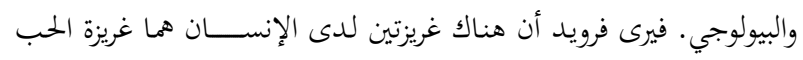

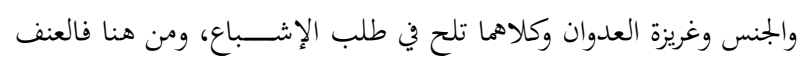

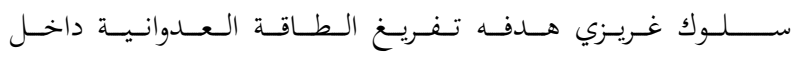
الإنسان(Fox,1999;pp88-103). أما العنف المكتسب فهو ذلك الذي يكتسـب أو يتعلمه الإنســان من البيئة المحيطة به عن طريق ملاحظة الإنسا نماذج لدى الاباء والاصـــقاء ومشــاهدة مظاهر العنف في أفلام التليفزيون

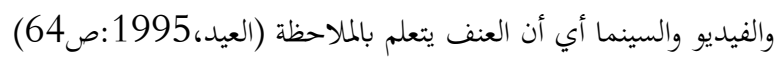
كما يمكن تقسيميم العنف إلى عنف بلدي وعنف نفسسي ويشسير الأول إلى

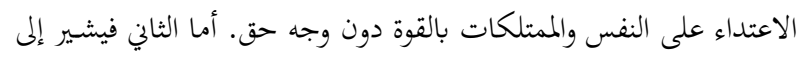

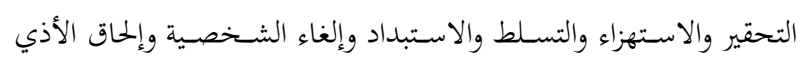
بالنفس بالغير و بآليات مختلفة. 
العنف لعدم وضـوح دور كل منهما فإنها تؤدي الى اضطراب العلاقات بين الزوجين وتفكك شــبكة العلاقات بينهم والتي تنعكس سـلبا على تماسـك تصك

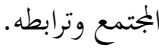

والعنف الاسري من شأنه ان يسهم في زيادة اضطراب المجتمع، فمعظم اشكال العنف الاسري إذا حدثت خارج الضوابط الشرعية فإنها تعتبر جرائم عنيفة في حد ذاتما، حيث تبدو خطورة هذه الجرائم وقوعها في اطار الاسـرة

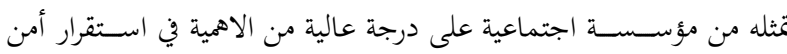

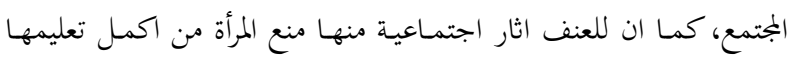
وذلك اما من خلال اجبار الاهل الفتاة على زواجها مبكرا وعدم استكمال تعليمها او لتفضـيل تعليم الابناء الذكور عن الاناث، بالاضـافة الى فقدان

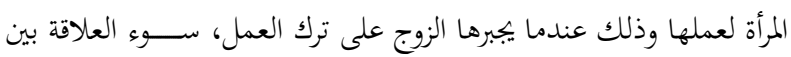
الآباء والابناء وبين الازواج، وبين الاهل والزوجة. وفي ضــوء ما سـبق يمكن القول بأن اثار العنف الاســري ونتائجه متداخلة

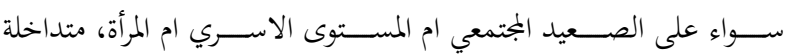

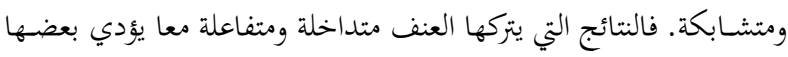
الى البعض الآخر ليشـكل خطرا فعليا يهدد البنية الاجتماعية والاقتصـادية للاسرة والمجتمع الى حد سواء. خامساً: الإجراءات المنهجية وخصائص عينة الدراسة الميدانية 1- الإجراءات المنهجية للدراسة أ- نوع الدراسة: تعد هذه الدراسة وصفية تحليلية، تتوخى الوقوف على اثر العنف الاسري الذي تتعرض له المرأة العاملة في المجتمع. ب- منهج الدراسة: سوف تعتمد الدراسة على أسلوب المسح الاجتماعي بطريقة العينة في جمع بيانات شاملة ومتعمقة حول موضوع الدراسة. ج- أدوات جمع البيانات(الاستبيان): تم استخدام استمارة الاستبيان في موقف المقابلة كوسيلة لجمع البيانات؛ وي ضوء اهداف الدراسة وتساؤلاتما. - صـدق وثبات الاستمارة: عملت الباحثة على تحقيق الصـدق الظاهري للأداة من خلال عرض استمارة الاستبيان على عدد من المحكمين المختصين في علم الاجتماع وذلك للحكم على مدى صـــلاحية الاســتمارة لإجراء الدراسـة الميدانية، واستخدمت الباحثة اسلوب اعادة الاختبار حيث قامت

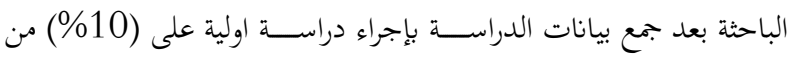

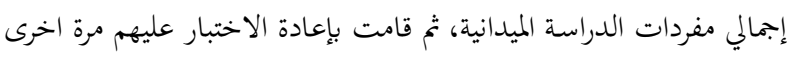
لقياس الثبات، وقد بلغ معامل الثبات (92\%) مما يدل على وجود درجة اتساق عليه بين إجابات المبحوثين. د- عينة الدراسـة: تم اختيار عينة الدراسـة من أسـر مدينة الديوانية بطريقة

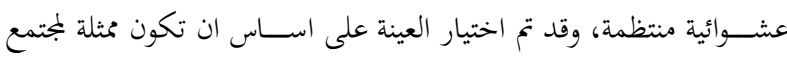
البحث وقد تمكنت الباحثة من الحصول والتعرف على حالات الدراسة من الأسر التي تعرضت للعنف الأسري في محكمة الاحوال الشخصية في مدينة الديوانية.

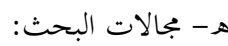

وخروج الزوجة للعمل و ما له من آثار سـلبية على العلاقات داخل الأسـرة

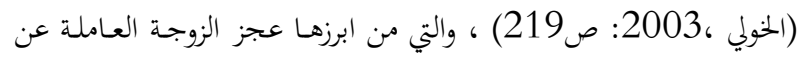
مواجهة متطلباها بشـكل يضـمن لها اسـتقرار نفسسي فتظل في صـراع بين تحقيق متطلبات وتوقعات الزوج والابناء من جهة وبين تحقيق ذامَا واهدافها

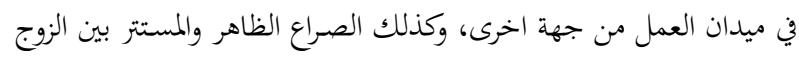
والزوجة على السـيادة المنزلية والادخار ومعاملة الاطفال والصـلة بالنسـق القرابي وتمضـية وقت الفراغ والذي يعتبر بدوره مســؤول عن بعض اشـكال

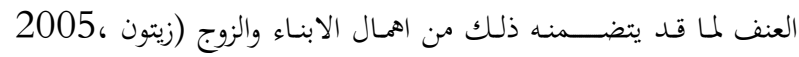

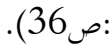
ومن حق المرأة على الرجل ان يرفق بها وان يلطف لها القول فهي مرهفة

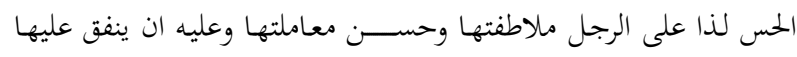
ويغدق عليا بالمال، وبسـبب النظام الاقتصـادي الذي كان قائم في السـابق حيث كان الرجل هو صــاحب السـلطة في خروجه للعمل والمرأة تبقى في

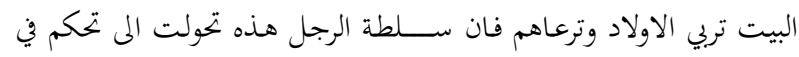
داخل العائلة، ومع تطور النظام الصــــاعي حصـــلت تطورات ديمغرافية

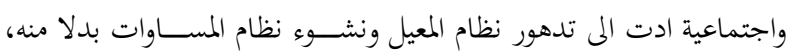
ومن هنا بدأت معاناة المرأة العاملة اذا فهي تتحمل مســؤوليات عمل بدوام

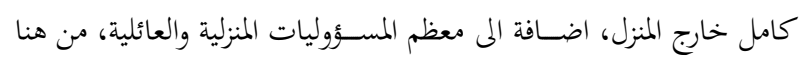

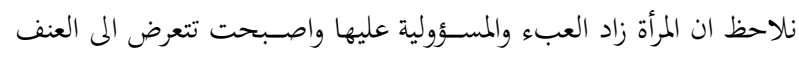

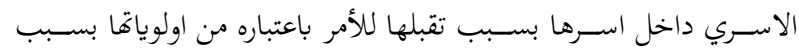

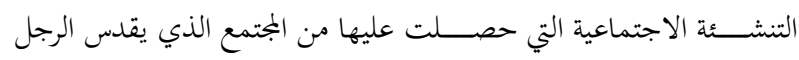
ويعتبره هو المسؤول عنها رغم استقلاليتها المادية بسبب عملها خارج المنزل لقد استشرى العنف في المجتمع العراقي وبشكل كبير خلال السنوات الاخيرة حيث لاحظنا ان العنف الاســـري هو نمط شــائع من العنف في المجتمع انطلاقا من مرجعية ثقافية تبريرية غالبا ما بتعل ممارســـة العنف بمثابة حق

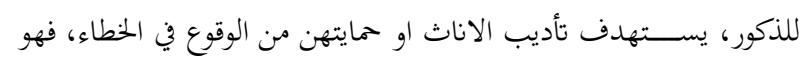
اجراء وقائي تأدبي ،يستند اساسا الى شكوك متوارثة بالمرأة .ان هذا النمط من العنف موجود في كـل مكــان من العراق ولم تبرا منـه المرأة (حزة والمشهداني، 2014:صن 203). رابعاً: آثار العنف الاسري

ان للعنف الاسـري ضـــ المرأة باختلاف انواعه واشـكاله اثار اجتماعية التي قد تترتب على العنف الاســري ضـــــ المرأة شـأفها شــأن بقية اثار الظاهرة

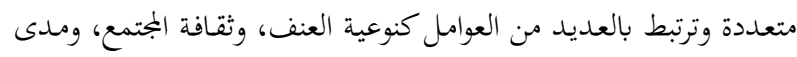
قدرة الضحية على تحمل الممارس ضدها. ويمكن ابراز اهم واخطر الاثار الاجتمـاعية في التصــــــع المادي والمعنوي

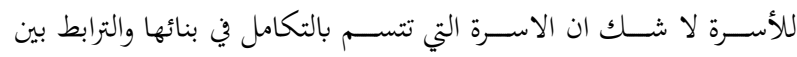
اعضائها، وتتسم ايضا بالتكامل والكفاية المادية والتوافق الثقافي والاخلاقي، فالعنف الممارس ضد المرأة احد الاسباب الرئيسة للتفكك الاسري، لما يمثله من مظهرا ســلبيا يعبر عن امتناع كل منهما عن الحياة الزوجية الطبيعية، حيث تتخلل هذه الحياة الاسـرية مشـكلات النزاع بين الازواج واسـتخدام 


\begin{tabular}{|c|c|c|c|}
\hline \multirow{3}{*}{ 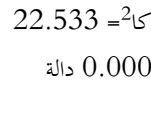 } & 71.7 & 86 & توجد \\
\hline & 28.3 & 34 & لا توجد \\
\hline & $\% 100$ & 120 & الجمهوع \\
\hline
\end{tabular}

كثــفت بيانات جدول(2) عن ان الغالبية العظمى للمبحوثات اللاتي لن

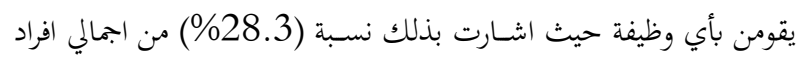

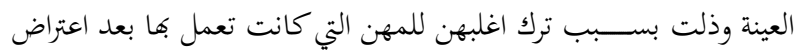

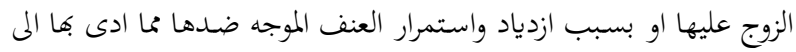

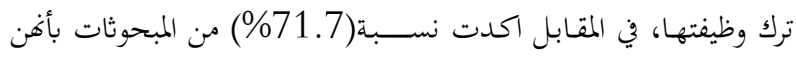

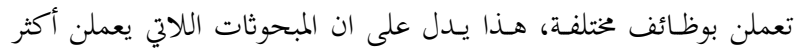

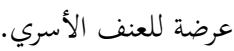

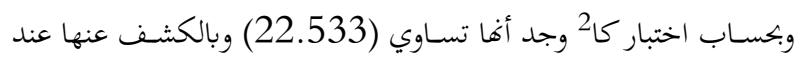

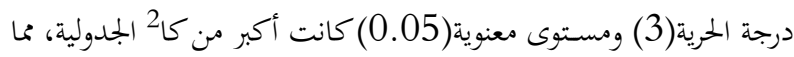

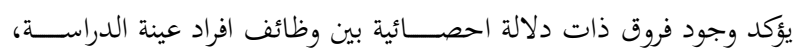

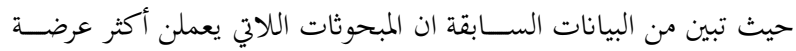

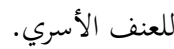

\begin{tabular}{|c|c|c|c|}
\hline كاع & $\%$ & التكرار & المستوى التعليمي \\
\hline & 1.7 & 2 & أمية \\
\hline \multirow{4}{*}{$\begin{array}{r}196.000={ }^{2} \text { كالة } 0.000 \\
\text { دالة }\end{array}$} & 6.7 & 8 & تقرأ وتكتب \\
\hline & 11.7 & 14 & متوسطة واعدادية \\
\hline & 80 & 96 & جامعية \\
\hline & 100 & 120 & الجموع \\
\hline
\end{tabular}

اسفرت بيانات جدول(3) عن ان اغلبية المبحوثات تعرضن للعنف الأسري

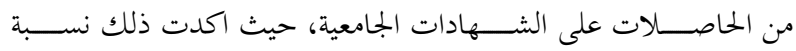

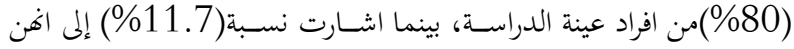

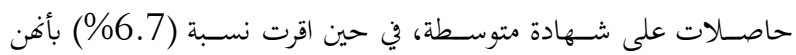

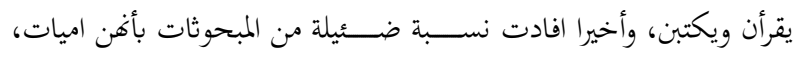

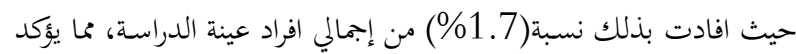
من البيانات انه كلما زاد المســتوى التعليمي للمبحوثات كلما تكون أكثر الماتر عرضـة للعنف الأسـري داخل إطار الأسـرة، ويعتبر التعليم من أهم العوامل

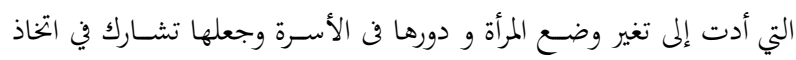

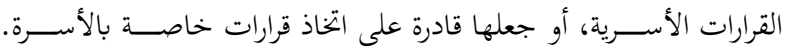
ونستتج من ذلك ان أغلب المبحوثات كن من اصحاب الشهادات وذات

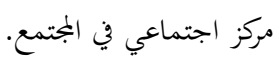

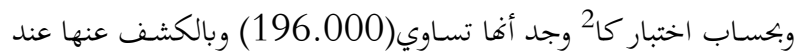

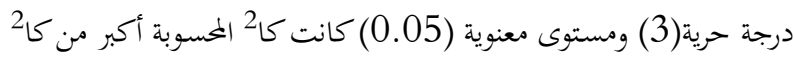

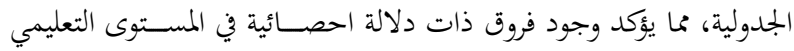
لأفراد عينة الدراسة، حيث تبين من البيانات اعلاه ان اكثر الفئات التعليمية تعرضا للعنف من اصحاب الشهادات الجامعية.

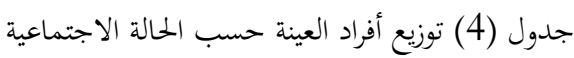

\begin{tabular}{|c|c|c|c|}
\hline كا2 & $\%$ & التكرار & الحالة الاجتماعية \\
\hline $53.333=$ كا2 & 83.3 & 100 & مطلقة \\
\hline 0.000 دالة & 16.7 & 20 & لمتزوجة متمة \\
\hline
\end{tabular}

1- الجحال البشري: يقصد به الأفراد الذين جرت عليهم الدراسة، وبما ان

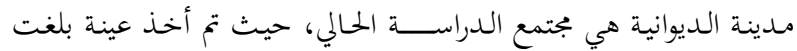

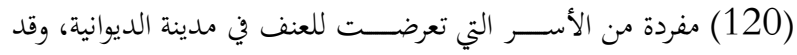
روعي عند اختيار عينة الدراسة ان تكون قمثلة لمجتمع البحث.

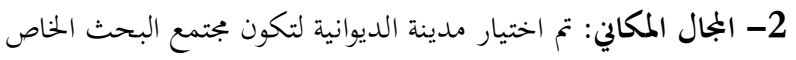

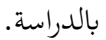
3- الجمال الزمني: ويقصد به الوقت الذي استغرقته الباحثة لإعداد البحث

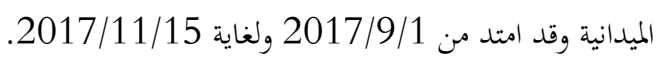
و - الاساليب الإحصائية المستخدمة في جمع البيانات: اعتمدت الباحثة

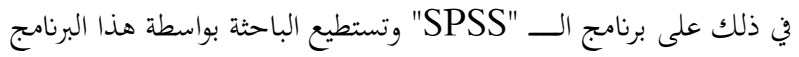
القيام باغلب المعاملات الاحصائية التي تحتاجها الدراسة.

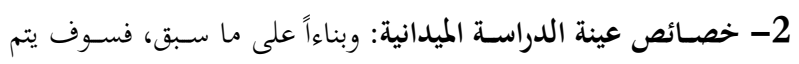

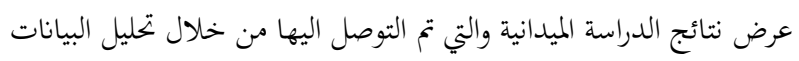
الإحصـائية للأسئلة الواردة في استمارة الاستبيان، وكذلك اهم التوصيات الخاصة بالدراسة الراهنة، وسوف يتم تناول كل هذه النقاط بالتفصيل كما

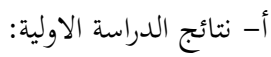

\begin{tabular}{|c|c|c|c|}
\hline${ }^{2}$ كا & $\%$ & العدد & فئات العمر \\
\hline \multirow{5}{*}{$\begin{array}{r}188.533={ }^{2} \text { كالة } 0.000 \text { دالة }\end{array}$} & 78.3 & 94 & $30-20$ \\
\hline & 16.7 & 20 & $40-30$ \\
\hline & 3.3 & 4 & $45-40$ \\
\hline & 1.7 & 2 & $50-45$ \\
\hline & 100 & 120 & الجمموع \\
\hline
\end{tabular}

اسفرت بيانات جدول(1) عن ان الغالبية العظمى من المبحوثات من اللاتي

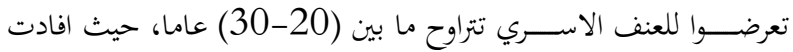

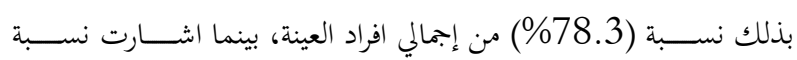

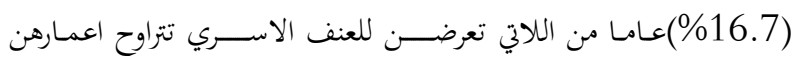
بين(30-40)عاما، في حين اقرت نســبة (3.3\%)عاما من المبحوثات

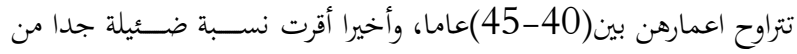

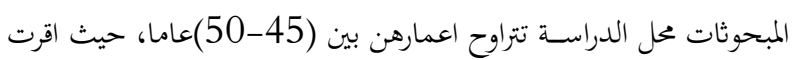

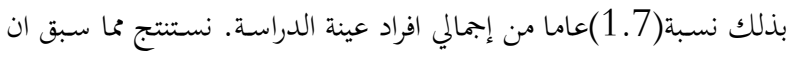

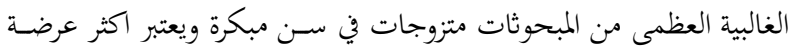
للعنف الاسري داخل إطار الأسرة، وهن من القادرات على العمل والانتاج

$$
\text { ولديهن اسر مسؤولات عنها. }
$$

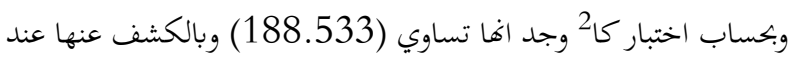

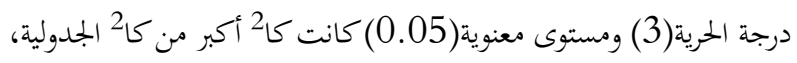

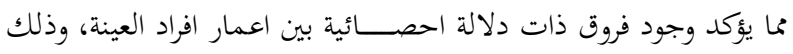

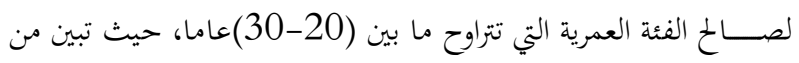
البيانات بأغن أكثر فئة عمرية معرضة للعنف الأسري. جدول (2) عمل المبحوثات

\begin{tabular}{|l|r|r|r|}
\hline مدى وجود الوظيفة & (2) \\
\hline
\end{tabular}




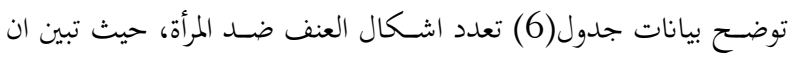

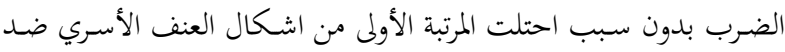

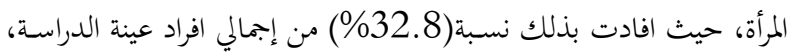

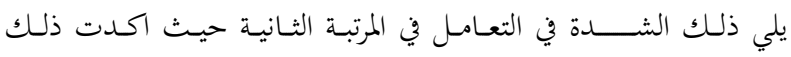
نســـ(29.8\%) من المبحوثات، يليها فرض الرأي في المرتبة الثالثة حيث اكليث

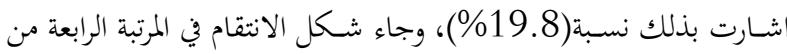

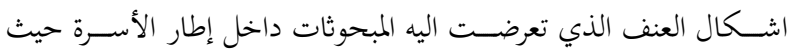

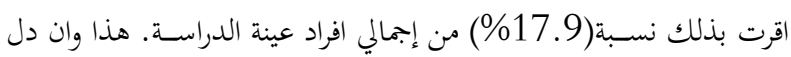

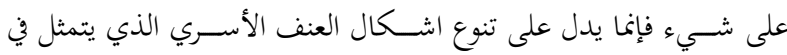
العنف المادي والمعنوي، حيث اكدت الغالبية العظمى من المبحوثات بأهن

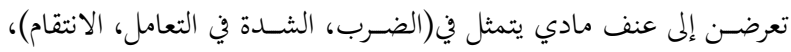

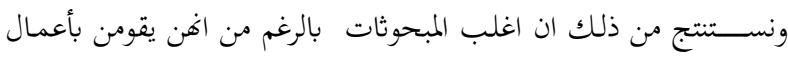

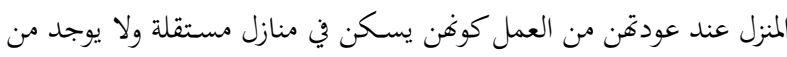

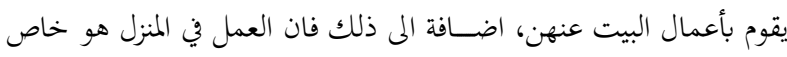

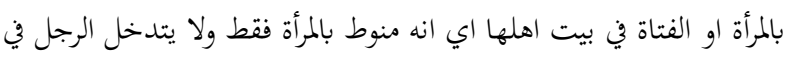

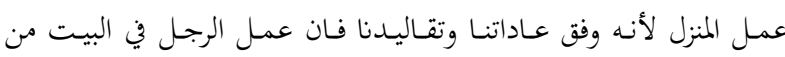

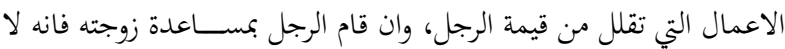

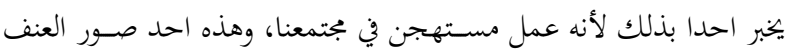
التي تتعرض لها المرة العاملة في اسرقا.

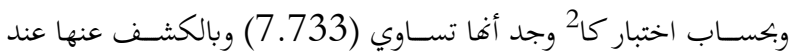

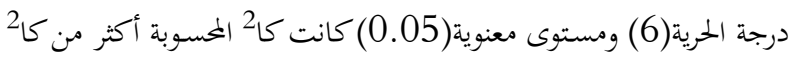

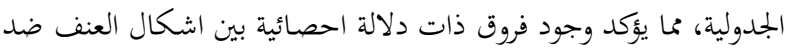

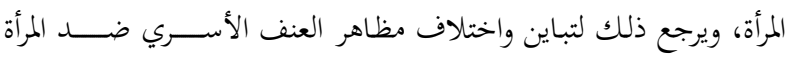

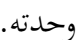
جدول(7) الإعلام سبب من أسباب العنف الأسري

\begin{tabular}{|c|c|c|c|}
\hline كا & $\%$ & التكرار & المتغير \\
\hline \multirow{3}{*}{$\begin{array}{c}4.800={ }^{2} \text { كالة } 0.028 \text { دال }\end{array}$} & 40 & 48 & نعم \\
\hline & 60 & 72 & ע \\
\hline & 100 & 120 & الجموع \\
\hline
\end{tabular}

اســفرت بيانات جدول(7) عن ان الغالبية العظمى من المبحوثات لا ترين

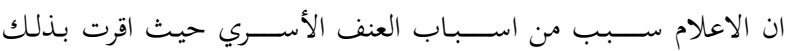

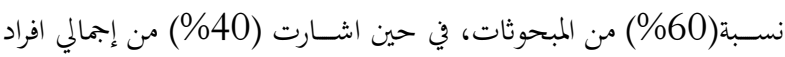

عينة البحث يرون ان الاعلام يكون سبباً من اسباب العنف الأسري.

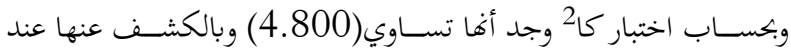

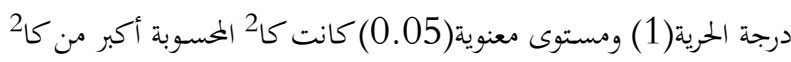

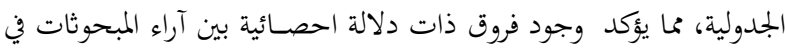

$$
\text { اعتبار الاعلام سبب من اسباب العنف الأسري. }
$$

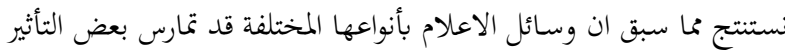

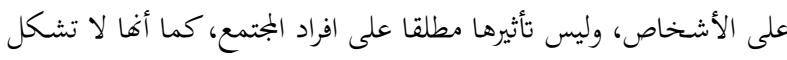

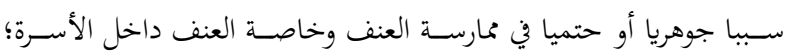
حيث يتوقف على مدى استجابة الشخص لها او مشاهدة وسائل الاعلام.

\begin{tabular}{|l|l|l|l|}
\hline & 100 & 120 & الجموع \\
\hline
\end{tabular}

اســفرت بيانات جدول(4) عن ان الغالبية من المبحوثات من المطلقات

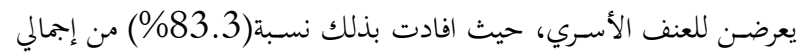
افراد عينة الدراسة، بينما اقرت نسبة(16.7\%) بأهن متزوجات ويتعرضن الأسن

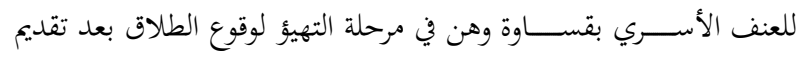

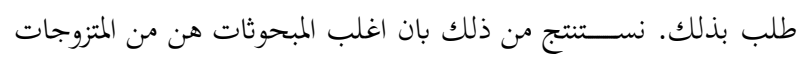
والمطلقات اللواتي لديهن اسر ينفقن عليهم واطفال يرعنهم.

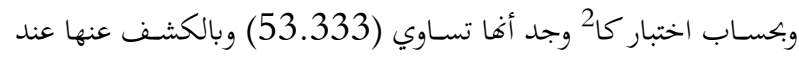
درجة الحرية(1) ومستوى معنوية(0.05) كانت كام المحسوبة أكبر من كال

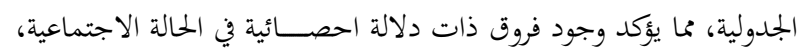
وذلك لصالح فئة المطلقات بأعتبارهن أكثر عرضة للعنف الأسري. جدول (5) توزيع أفراد العينة حسب عدد الأبناء

\begin{tabular}{|c|c|c|c|}
\hline كا2 & $\%$ & التكرار & عدد الأبناء \\
\hline \multirow{5}{*}{ 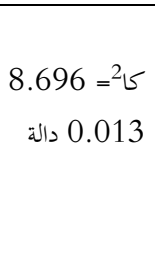 } & 26.7 & 32 & واحد \\
\hline & 36.7 & 44 & اثنين \\
\hline & 30 & 36 & ثلاثة فأكثر \\
\hline & 6.6 & 8 & لا يوجد ابناء \\
\hline & 100 & 120 & الجموع \\
\hline
\end{tabular}

يتبين من بيانات جدول(5) ان ما يقرب من ثلث عينة الدراســة لديهن

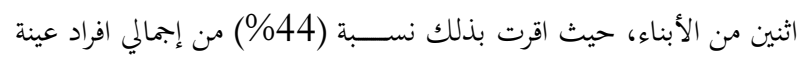

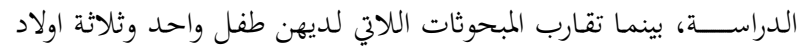

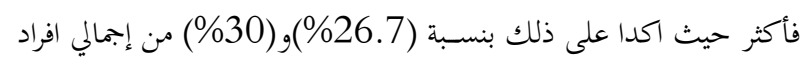

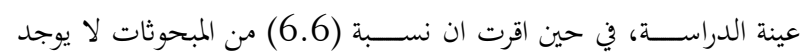
لديهن ابناء. وبكسـاب اختبار كا2 وجد أخها تسـاوي(30.696) وبالكشف عنها عند

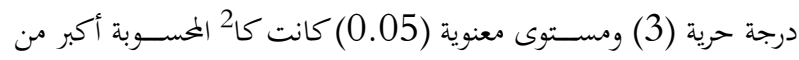

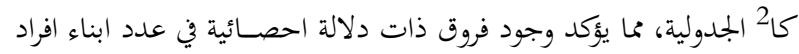

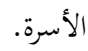
ب- العنف الأسري الذي تواجهه المرأة وأسبابه:

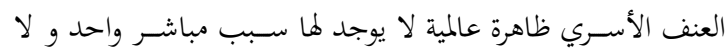

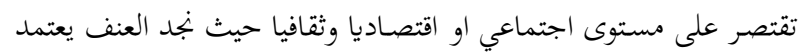

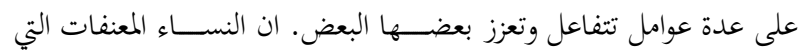

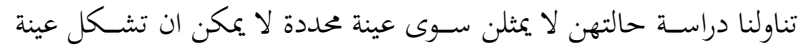

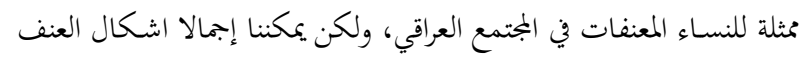

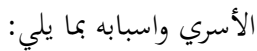
جدول(6) يوضح اشكال العنف ضد المرأة(أكثر من استجابة)

\begin{tabular}{|c|c|c|c|}
\hline كا & $\%$ & التكرار & المتغير \\
\hline \multirow{4}{*}{ 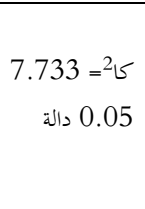 } & 32.8 & 44 & الضرب بدون سبب \\
\hline & 17.9 & 24 & الانتقام \\
\hline & 29.8 & 40 & الشدة في التعامل \\
\hline & 19.5 & 26 & فرض الرأي \\
\hline
\end{tabular}




\begin{tabular}{|c|c|c|c|}
\hline كا2 & $\%$ & التكرار & نوع الإجابة \\
\hline \multirow{3}{*}{ 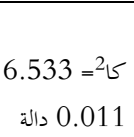 } & 61.7 & 74 & نعم \\
\hline & 38.3 & 46 & $y$ \\
\hline & 100 & 100 & المجموع \\
\hline
\end{tabular}

اســـفرت بيانات جدول(10) عن ان الغالبية العظمى من المبحوثات ترين

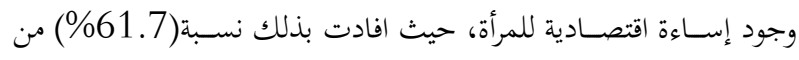
إجمالي أفراد عينة البحث، في حين اشارت نسبة (38.3\%) من المبحوثات

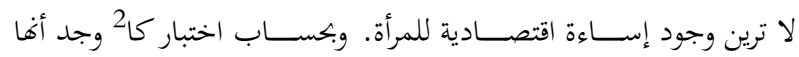

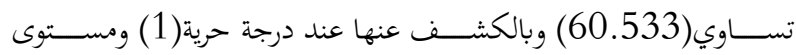

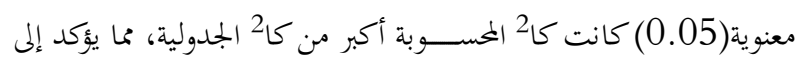

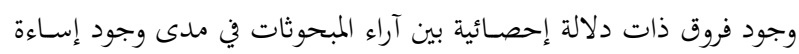

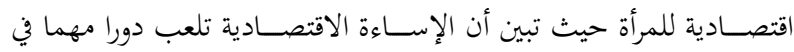
ارتكاب العنف ضد المرأة داخل الأسرة. جدول (11) يوضح بأن العنف يرجع للعادات والتقاليد

\begin{tabular}{|c|c|c|c|}
\hline كا2 & $\%$ & التكرار & المتغير \\
\hline \multirow{3}{*}{$\begin{array}{r}0.533=25 \text { كالة } 0.465 \text { دالة }\end{array}$} & 53.3 & 64 & نعم \\
\hline & 46.7 & 56 & كلا \\
\hline & 100 & 120 & الجمموع \\
\hline
\end{tabular}

تشسير بيانات جدول(11) إلى ان أكثر من نصـف عينة الدراسـة أكدوا أن

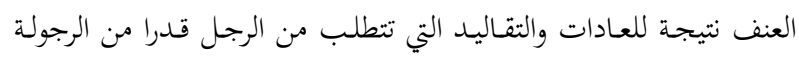

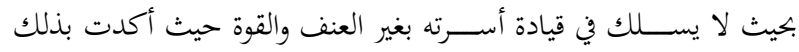

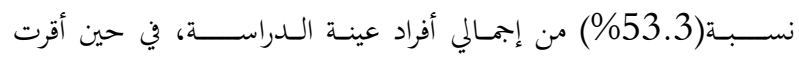
نســبة(46.7\%) من المبحوثات بأهن لا يرين أن العنف نتيجة للعادات

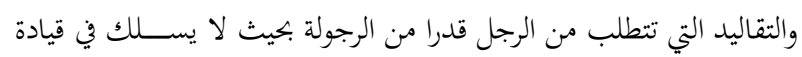
أسرته بغير العنف والقوة.

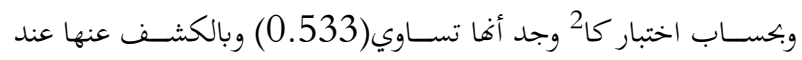

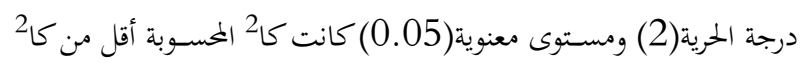
الجدولية، مما يؤكد عدم وجود فروق ذات دلالة احصائية بين آراء المبحوثات في مدى اعتبار العنف نتيجة للعادات والتقاليد التي تتطلب من الرجل قدرا من الرجولة بحيث لا يسلك في قيادة أسرته بغير العنف والقوة.

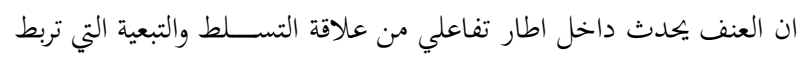
الازواج والزوجات والابناء في مؤسـسـة متآلفة يطلق عليها المنزل، وان هذا

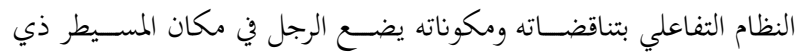
السلطة داخل هذا البناء. ج- أشكال العنف الأسري الذي تتعرض له المرأة العاملة ومظاهره:

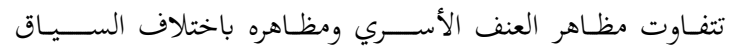
الاجتماعي والاقتصادي والسياسي والثقافي في مجتمع ما، فربما تزداد بعض أنس

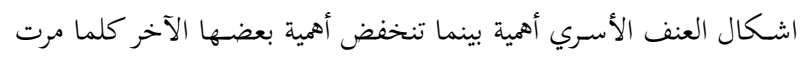

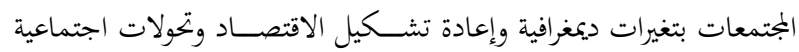

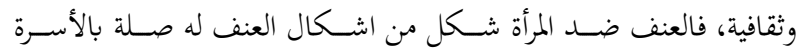

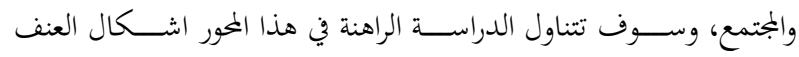

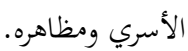

جدول (8) يوضــح تعرض المرأة العاملة الى التعنيف من قبل الزوج او الوالد او الاخ الاكبر اذا تأخرت في العمل ساعات اضافية

\begin{tabular}{|c|c|c|c|}
\hline كا2 & $\%$ & التكرار & نوع الإجابة \\
\hline \multirow{3}{*}{ 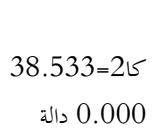 } & 88.3 & 106 & نعم \\
\hline & 11.7 & 14 & V \\
\hline & 100 & 120 & الجمموع \\
\hline
\end{tabular}

توضـح بيانات جدول(8) أن (106) من المبحوثات وبنسـبة (88.3\%) كن يتعرضـن الى التعنيف من قبل اولياء امورهن اذا تأخرن في العمل، بينما (14) من المبحوثات وبنسبة (11.7\%) كان لا يتعرضن الى التعنيف.

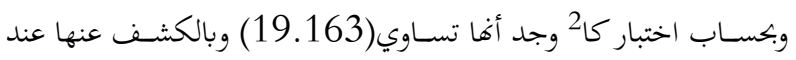
درجة الحرية(2) ومستوى معنوية(05.05) كانت كا2 المحسوبة أكبر من كا2 الجدولية، مما يؤكد وجود فروق ذات دلالة احصـائية في تعرض المرأة العاملة

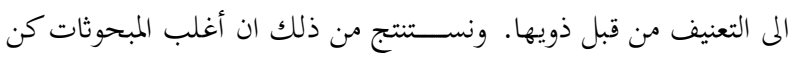
يتعرضـن للتعنيف اذا تأخرن في العمل سـاعات اضـافية عن الوقت المحدد لخروجهن من العمل رغم كوهن يذهبن الى العمل للحصول على مردود مالي لئل

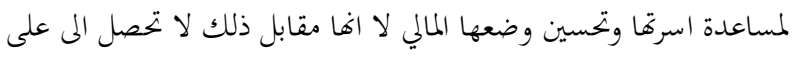
التعنيف بحجج الخوف عليهن وحمايتهن ولكن كل ذلك يؤكد مدى تسـلط

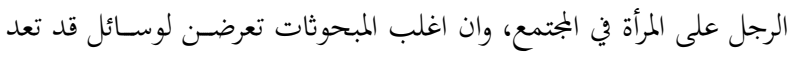
عنف مهـد للحياة وهي تهديد لحياة المرأة أو الزوجة بأداة مثل(التهديد بسكين، والتهديد بمسدس، والضرب الشديد الذي يؤدي إلى كسور مثلا).

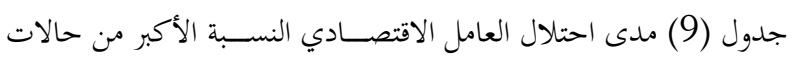

العنف ضد النساء

\begin{tabular}{|c|c|c|c|}
\hline كا2 & $\%$ & التكرار & المتغير \\
\hline \multirow{3}{*}{$\begin{array}{c}13.333={ }^{2} .3000 \\
0.000 د ا ل ة ~\end{array}$} & 66.7 & 80 & نعم \\
\hline & 33.3 & 40 & $y$ \\
\hline & 100 & 120 & الجموع \\
\hline
\end{tabular}

تشير بيانات جدول(9)إلى ان غالبية المبحوثات ترين ان العامل الاقتصادي

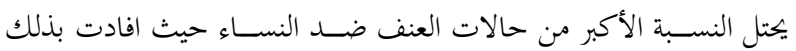

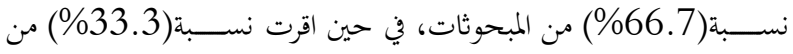

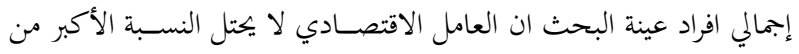
حالات العنف ضـد النسـاء. هذا يؤكد ان اسباب ضـرب الرجل للمرأة التي ترجع لعوامل اقتصـادية، ولعل اهم هذه العوامل الاقتصـادية حيث تبين ان اكثر من نصـف المبحوثات اللاتي تعرضـن للعنف داخل إطار أسـرةن كان السبب في ذلك هو الصراع حول المبالغ المادية.

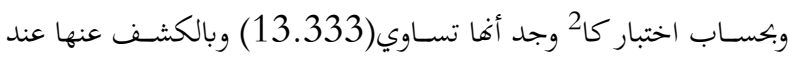
درجة الحرية(1) ومستوى معنوية(05.05) كانت كا2 المحسوبة أكبر من كا2 2 الجدولية، مما يؤكد وجود فروق ذات دلالة احصـائية بين آراء المبحوثات في

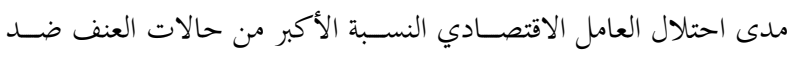

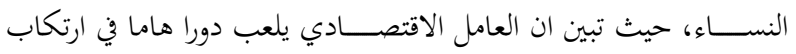
العنف ضد المرأة داخل الأسرة. جدول (10) يوضح مدى وجود إساءة اقتصادية للمرأة 
على المرأة. ويكون العنف اللفظي على شـكل احراج لزوجته امام الآخرين،

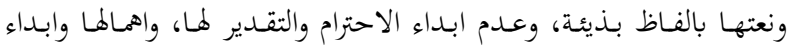

الاعجاب بالآخريات في حضورها وتحقيرها. نستتنج من ذلك ان هناك آثار نفسية وجسـية التي تنجم عن تعرض المرأة

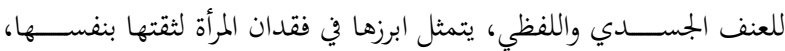

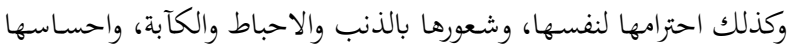
بالعجز والاذلال والمهانة، وعدم الشـعور بالاطمئنان، وفقدان الاحســاس بالمباردة واتخاذ القرار.

\begin{tabular}{|c|c|c|c|}
\hline كا2 & النسبة المئوية & التكرار & المتغير \\
\hline \multirow{4}{*}{$\begin{array}{r}22.400={ }^{2} .000 \text { كالة } 0.000 \text { دالة }\end{array}$} & 26.7 & 32 & اللجوء الى الاهل \\
\hline & 20 & 24 & اللجوء الى المحكمة \\
\hline & 53.3 & 64 & 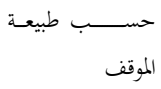 \\
\hline & 100 & 120 & الجموع \\
\hline
\end{tabular}

توضـح بيانات جدول(14) رد فعل المبحوثات بتحاه ضربكن، حيث تبين ان اكثر من نصف عينة الدراسة من المبحوثات ترين ان طبيعة الموقف يعد اهم

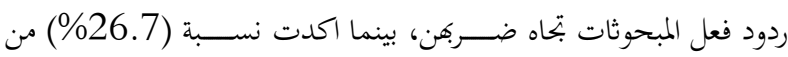

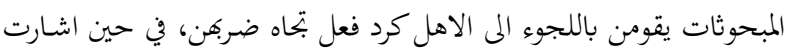
نسـبة (20\%) من المبحوثات المى اهن يقومن باللجوء الى المحكمة في حالة

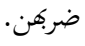
وبحسـاب اختبار كا2 وجد اها تسـاوي(22.400) وبالكشـف عنها عند درجة الحرية(2) ومســتوى معنوية (0.05) كانت كا2 المحســوبة اكبر من ونس

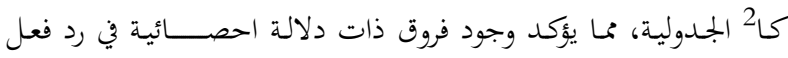
المبحوثات بحاه ضــربهن، حيث اكدت البيانات على تعدد ردود المبحوثات تحاه ضربكن في طبيعة الموقف، اللجوء المى الاهل او المحكمة. نسـتنتج من ذلك أن اغلب النســاء اللواتي يتعرضـن للعنف لم يخبرا احدا بذلك اما بسبب خوفهن من ازواجهن او خوفهن على بيوتن من التخريب

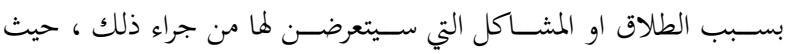
نلاحظ ان المرأة في المجتمع العراقي تحاول بشــتى الطرق المحافظة على بيتها واطفالها من الضـياع بسـبب الطلاق، وان هذا السـكوت على العنف هو

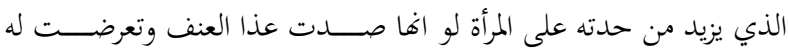
بالشــكوى القضـــائية او المى الاهل والمقربين منها لوجدت لهـ له الحل بدل

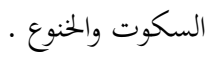
سادسأ: النتائج العامة والتوصيات

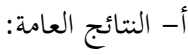
1- تبين من البيانات ان الفئة العمرية التي تتراوح ما بين (20-30)عاما بأفن أكثر فئة عمرية معرضة للعنف الأسري.

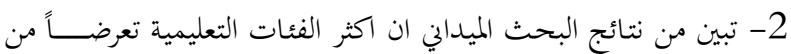
اصحاب الشهادات الجامعية.
جدول (12) اشكال العنف الذي تواجهه المرأة

\begin{tabular}{|c|c|c|c|}
\hline كا2 & $\%$ & التكرار & المتغير \\
\hline \multirow{5}{*}{$\begin{array}{r}19.163={ }^{2}=1001 \text { دالة } 0.001 \\
\text { دالة }\end{array}$} & 43.3 & 52 & الضرب \\
\hline & 20 & 24 & السخرية \\
\hline & 23.3 & 28 & الحيانة \\
\hline & 20 & 24 & الهجر \\
\hline & 100 & 120 & المجموع \\
\hline
\end{tabular}

توضح بيانات جدول(12) اشكال العنف الذي تواجهه المرأة، حيث تبين أن الضرب يعد أهم أشكال العنف الذي تواجهه المرأة حيث افادت بذلك

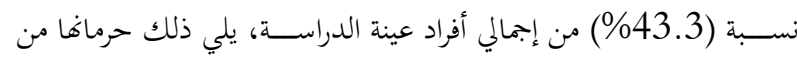

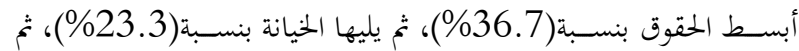

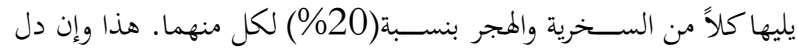
على شيء فإنما يدل على تعدد اشكال العنف الذي تواجهه المرأة يتمثل في

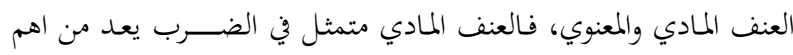
اشكال العنف اتحاه الزوجة، يليها العنف المعنوي متمثل في السخرية والخيانة والهجر. وبحسـاب اختبار كا2 وجد أها تسـاوي(19.163) وبالكشـف عنها عند درجة الحرية(2) ومستوى معنوية(0.05) كانت كا2 المحسوبة أكبر من كا2

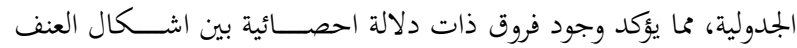
الذي تواجهه المرأة. نسـتنتج من ذلك ان العنف الجسـدي كأحد اشـكال العنف ضـد المرأة فإن المرأة عندما يمارس ضــدها العنف الجســدي من جانب ذويها، وعادة تتمثل هذه الافعال او الاشكال في الضـرب وهو فعل حاضـر التي يسودها التوتر

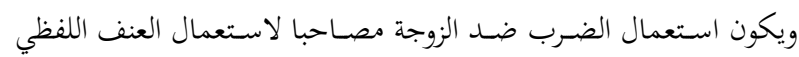
حيث تتعرض الزوجة وهي تضرب للسب والاهانة والتهديد.

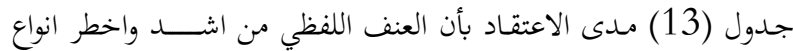
العنف خطرا على المرأة

\begin{tabular}{|c|c|c|c|}
\hline كا2 & النسبة المئوية & التكرار & المتغير \\
\hline \multirow{3}{*}{$\begin{array}{r}30.000={ }^{2} \text { كالة } 0.000 \text { دالة } \\
\text { دا }\end{array}$} & 75 & 90 & نعم \\
\hline & 25 & 30 & كلا \\
\hline & 100 & 120 & الجمموع \\
\hline
\end{tabular}

تشير بيانات جدول(13) إلى ان نسبة (75\%) من المبحوثات تعتقدن ان

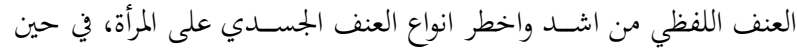

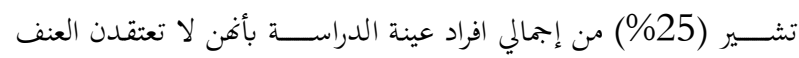
اللفظي من اشد واخطر انواع العنف الجسدي على المرأة. ونسـتنتج من ذلك ان الرجل يبقى في شـك وغيرة على زوجته مهما بلغت

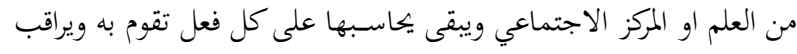
تحركاتا واتصالاتما حتى مع صديقاةًا .

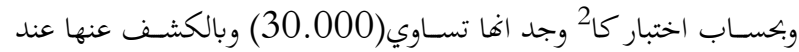
درجة درجة حرية(1) ومســتوى معنوية (0.05) كانت كا2 اكبر من كا2 الجدولية، مما يؤكد وجود فروق ذات دلالة احصــائية بين آراء المبحوثات في

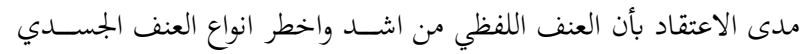


: المصادر

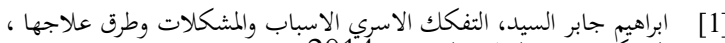

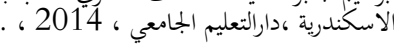

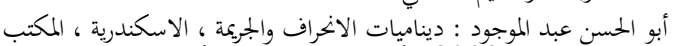

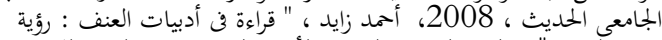

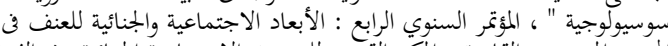

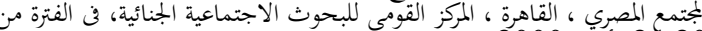
، 20

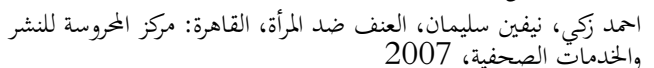

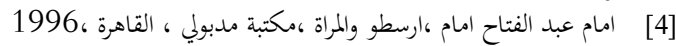

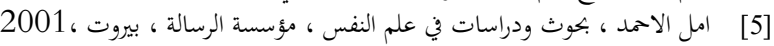

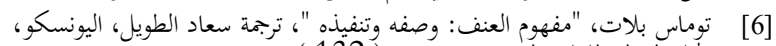

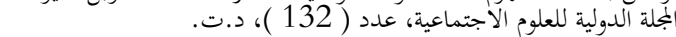

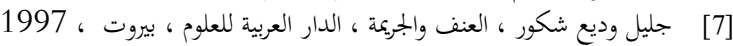

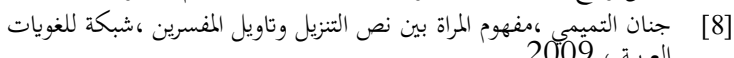

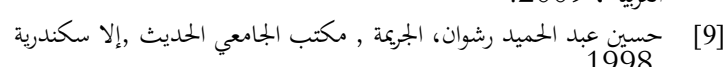
[10] حيدر البصرى : العنف الاسرى - الدوافع والحلول ، الاردن ، دار البيضاء للطباعة

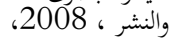
[11] سامى مكى : اشكالية العنف - العنف المشروع والعنف المدان ، بيروت ، المؤسسة

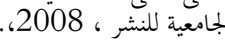

[12] سامية حسن الساعاتى : المرأة والبتمع المعاصر ، القاهرة ، الهيئة المصرية العامة

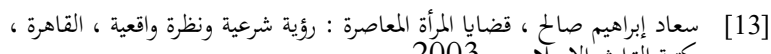

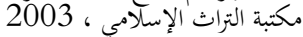

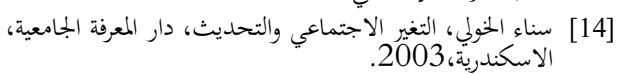

[15] سهيلة عبد الانيس ، العنف الطائفي في العراق ،بحث منشور في مؤتمر السليمانية

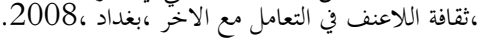

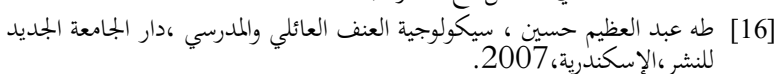

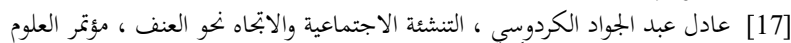

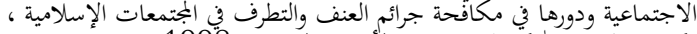

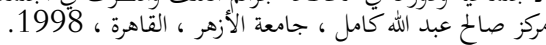

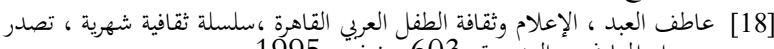

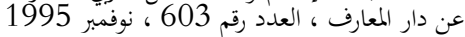
[19] عاطف غيث، المشاكل الاجتماعية والانراف السلوكي، دار المعارف، الاسكندرية،

[20] عرفات زيدان خليل، الاتحاهات الحديثة في دراسة ظاهرة العنف ودور الحدمة

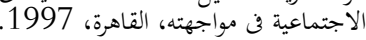

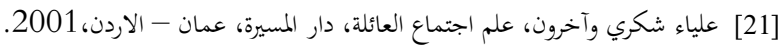

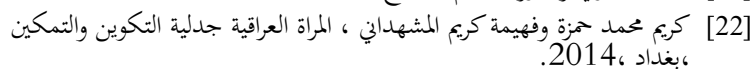

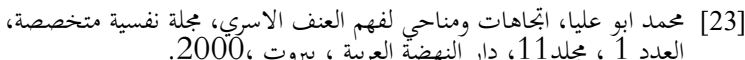

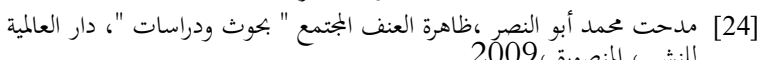
[25] المعجم العربي الأساسي، المنظمة العربية للتربية والثقافة والعلوم، 1989

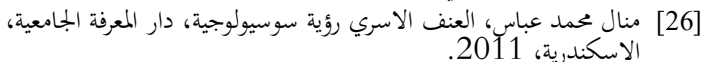

[27] منذر عرفات زيتون، الصحة والعنف، المجلس الوطنية لشؤون الاسرة، منظمة الصحة

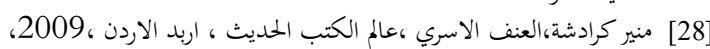

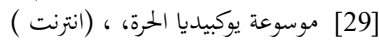

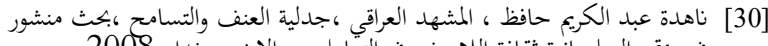

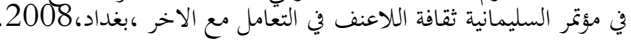

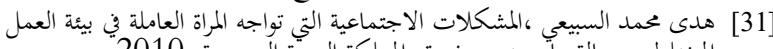

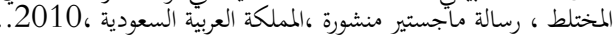

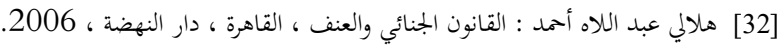

Ambrosino social work and social welfare :An [33] introuduction : United states Rosali Brooks/cold:2001:p340.

Bobic Lesely, aing \& Natasha Economic ,Costs of [34] Domestic Violence, University of New south Wales, Australia 2002,p115

Kathryn j. Fox, Changing Violent minds: Discusive [35] correction and Resistance in the cognitive Treatment of violent offenders in prison, University
3- تبين من نتائج البحث الميدائ ان المبحوثات اللاتي يعملن أكثر عرضـة

$$
\text { للعنف الأسري. }
$$

4- تبين من البيانات ان اكثر الفئات التعليمية تعرضا للعنف من اصحاب

الشهادات الجامعية.

5- ان اكثر النساء العاملات اللواتي يتعرضن للعنف هن من فئة المطلقات

$$
\text { باعتبارهن أكثر عرضة للعنف الأسري. }
$$

6- تباين وتختلف مظاهر العنف الأسري ضد المرأة وحدته.

7- تتعرض المرأة العاملة الى التعنيف من قبل ذويها اذا تأخرن في العمل.

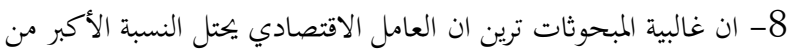
حالات العنف ضـــ النسـاء حيث تبين ان العامل الاقتصـادي يلعب دورا هاما في ارتكاب العنف ضد المرأة داخل الأسرة.

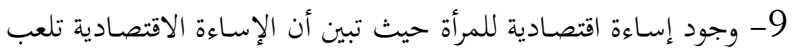
دورا مهما في ارتكاب العنف ضد المرأة داخل الأسرة.

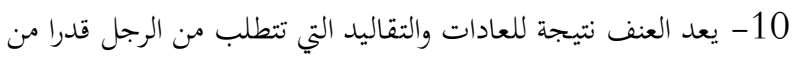
الرجولة بحيث لا يسلك في قيادة أسرته بغير العنف والقوة. 11- تعدد اشـــكال العنف الذي تواجهه المرأة يتمثل في العنف المادي والمعنوي، فالعنف المادي متمثل في الضرب يعد من اهم اشكال العنف ابتحاه الزوجة، يليها العنف المعنوي متمثل في السخرية والخيانة والهجر.

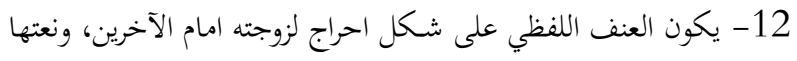

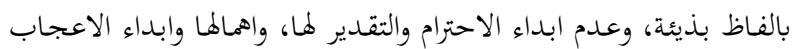

$$
\text { بالآخريات في حضورها وتحقيرها. }
$$

13- اكدت البيانات على تعدد ردود المبحوثات بتحاه ضـــربكن في طبيعة

$$
\text { الموقف، اللجوء الى الاهل او المحكمة. }
$$

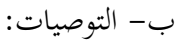

1- زيادة الوعي الثقـافي بين النـاس لتعريف المواطن بحجم ظـاهرة العنف

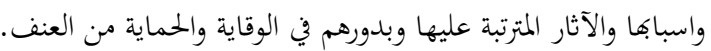
2- التزام كافة الجهات المتعـاملة مع حسالات العنف الأســـــي كأجهزة الشــرطة والمحاكم بتوفير الحماية والرفق والخصــوصـية لهؤلاء الضــحايا في

$$
\text { الإجراءات التي يتم التعامل معها. }
$$

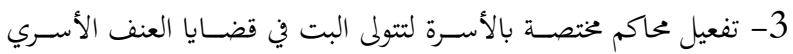
ويستعان فيها بخبراء في العنف الأسري من كافة التخصصات.

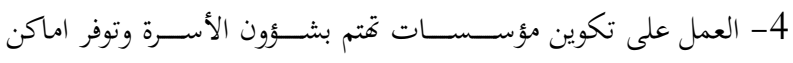

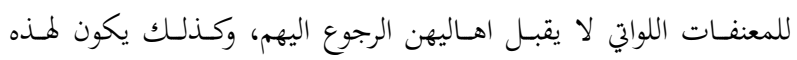

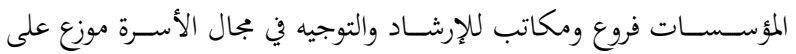
المناطق وتعمل هذه المؤسـسـة على نشـر الوعي بين الأهالي لأهمية استقرار

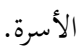
5- دور الأئمة والخطباء بتوضيح نظرة الشرع للعنف الأسري وتوعية الناس. 6- إدراج حقوق الأسـرة والوقاية والتصـدي للعنف الأسـري ضـمن المناهج في كافة المراحل التعليمية. 
of California press, Vol 46, No. 1, 1999, pp. 88-

Lenore E. Walker, Psychology and Domestic [36] violence around the world American psychological

Association the world American psychological

Association Vol-54,No.1, January, 1999,pp.21-

Lenore E. Walker, Psychology and Domestic [37] violence around the world American psychological

Association the world American psychological

Association Vol-54,No.1, January , 1999,pp.21-

Williams, R. Soul Sources of Marital Violence and [38] Deterrence journal of Marriage and the family

(Aug), 1992,pp.620-622. 